\title{
Distorting Legal Principles
}

\section{Steven L. Schwarcz*}

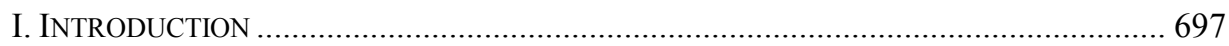

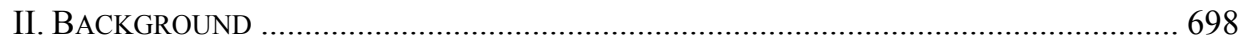

III. REHYPOTHECATION AND INTERMEDIARY RISK..................................................... 702

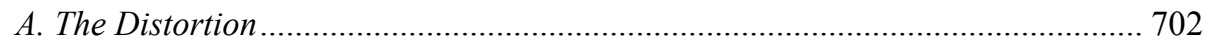

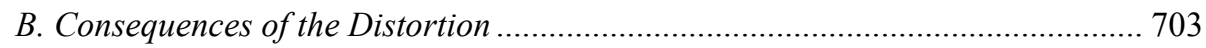

C. Towards a Framework for Balancing Consequences ........................................ 705

1. Balancing Consequences ........................................................................... 705

2. Adjusting the Balancing for Potential Bias .............................................. 706

3. Informing the Balancing Through Long-Standing Distortions.................... 708

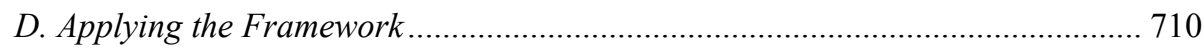

IV. OTHER DisTORTIONS AND THEIR CONSEQUENCES .............................................. 713

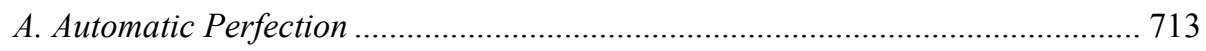

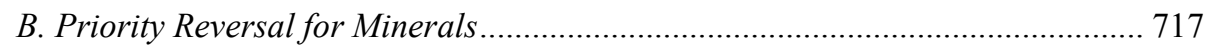

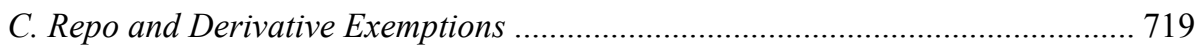

D. Restatement of the Framework ....................................................................... 721

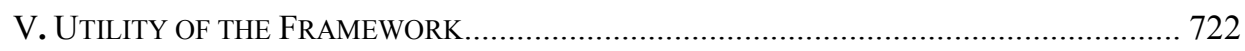

A. Application to Government Lawmaking ....................................................... 723

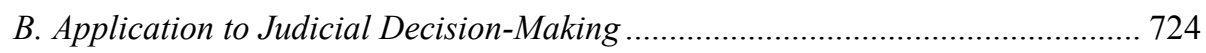

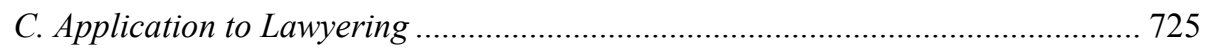

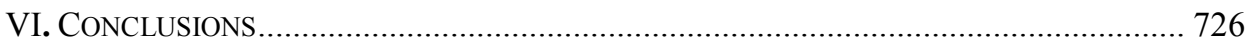

\section{INTRODUCTION}

Legal principles enable society to order itself by preserving broadly based expectations. Sometimes, however, parties transact in ways that are so inconsistent with generally accepted principles as to create uncertainty or confusion that undermines the basis for reasoning afforded by the principles. Such a distortion might occur, for example,

* Stanley A. Star Professor of Law \& Business, Duke University School of Law; Founding/Co-Academic Director, Duke Global Capital Markets Center. E-mail: schwarcz@law.duke.edu. The author thanks Joseph Blocher, George Christie, Kenneth Kettering, Marin Levy, Shami J. Patel, Daniel Schwarcz, Paul Shupack, and Lodewijk Van Setten for valuable comments and Sean MacGregor and Aakash Desai for invaluable research assistance. 
if a normally mandatory legal rule were unexpectedly treated as a default rule. This Article explores the problem of distorting legal principles, initially focusing on rehypothecation, a distortion whose uncertainty and confusion contributed to the downfall of Lehman Brothers and the resulting global financial crisis. But not all distortions are, on balance, harmful; sometimes they represent a positive evolution of law. To this end, this Article also seeks to construct a normative framework for determining how lawmakers, judges, and lawyers should address distortions of legal principles.

This Article explores the important but until now largely neglected problem of distorting legal principles, usually for business ends. ${ }^{1}$ The exploration starts by examining a fundamental distortion of the legal principle of nemo dat quod non habet ("nemo dat") - one cannot give what one does not have. This distortion, resulting from a practice known as rehypothecation, ${ }^{2}$ caused a type of intermediary risk ${ }^{3}$ that was at the heart of the recent global financial crisis and threatens to trigger future such crises. ${ }^{4}$

Using this distortion of nemo dat, this Article constructs a framework for analyzing distortions of legal principles. ${ }^{5}$ The central normative issue is when to allow or tolerate these types of distortions, given their potential costs. A proposed distortion might appear to be socially favorable on a simple balancing of costs and benefits, but there is also a chance it might end up seriously harming the public. This is especially likely when private interest groups favor the distortion, because they would almost certainly receive a disproportionate share of the benefits with the public potentially suffering a disproportionate share of any harm.

Because of the potential for significant public harm, this Article argues that distortions of legal principles should be assessed not on a simple cost-benefit basis but by a higher standard. A heavily-outweigh balancing test, this Article contends, can help to rebalance distributive effects of the distortions. This Article also examines which individuals and institutions should make the assessment and how they might do so.

\section{BACKGROUND}

A distortion of nemo dat resulted in a type of intermediary risk that was central to the recent financial crisis. ${ }^{6}$ Intermediary risk, generally, is the risk that property held by an intermediary on behalf of third parties may be seized by creditors of the intermediary. 7

1. The text accompanying infra notes 20-23 discusses in detail what would constitute such a distortion of a legal principle.

2. Rehypothecation is described infra notes $10-15$ and accompanying text.

3. Intermediary risk is defined infra note 7 and accompanying text (describing the cases of the recent financial crisis).

4. See infra notes $15-19$ and accompanying text.

5. Part $\mathrm{V}$ of this Article examines how individuals and institutions could apply this framework on a practical level (discussing risk and the onset of the financial crisis).

6. See infra notes 16-19 (discussing how this distortion triggered the collapse of Lehman Brothers).

7. Steven L. Schwarcz, Intermediary Risk in a Global Economy, 50 DuKE L.J. 1541, 1565 (2001). The intermediary risk addressed by this Article - that an intermediary may fail to return a customer's securities (or equivalent securities) - is a subset of counterparty risk. Counterparty risk is the risk that Party A, who relies on Party B's performance, will be harmed if Party B fails to perform. See, e.g., PETER MOLES \& NiCHOLAS TERRY, THE HANDBOOK OF INTERNATIONAL FINANCIAL TERMS 117 (1997) (defining counterparty risk as "[t]he credit risk assumed when undertaking a transaction with another party that they will be unable or unwilling to honour 
This risk has great practical importance where the property held by the intermediary is investment securities (hereinafter "securities") and the intermediary is a broker-dealer, bank, or other financial services firm ${ }^{8}$ holding the securities on behalf of third-party investors (hereinafter, "investors" or "customers" of the intermediary). ${ }^{9}$

Intermediary risk can arise in several ways. ${ }^{10}$ The intermediary risk at issue in the financial crisis resulted from a distortion of nemo dat caused by a globally widespread, albeit abstruse, ${ }^{11}$ practice called "rehypothecation." Rehypothecation occurs when an intermediary holding securities on behalf of investors - often a broker-dealer acting as prime broker for its customers ${ }^{12}$ - grants a security interest in (or otherwise encumbers) those securities in order to obtain financing for itself. ${ }^{13}$

Rehypothecation has good business justification: enabling intermediaries to obtain low-cost financing. ${ }^{14}$ However, its distortion of nemo dat creates uncertainty whether

their commitments").

8. In the United States, the Uniform Commercial Code (U.C.C.) refers to such an intermediary as a "securities intermediary." U.C.C. § 8-102(a)(14) (2009).

9. Schwarcz, supra note 7, at 1547-57.

10. For a discussion of other ways that intermediary risk can arise, see $i d$. at 1557-65. For example, intermediary risk can arise under the indirect holding system for recording rights in securities, which creates a risk that investors may not have actual property rights in the securities they purport to own, merely contractual claims against the intermediary for the securities. $I d$. at $1555-57$. If investors merely have contractual claims, their claims would be pari passu with —and thus subject to dilution by — claims of the intermediary's creditors. Id. See also Steven L. Schwarcz, Indirectly Held Securities and Intermediary Risk, 6 UNIF. L. REV. 283 (2001).

11. Perhaps because of rehypothecation's complexity, and also because laws concerning rehypothecation are limited and obscure, the widespread practice of rehypothecation has not enabled its distortions to become generally accepted. See infra notes 29, 70-71, and accompanying text (observing that although rehypothecation has been widespread and longstanding for well over a century, the law has not yet adequately coped with its uncertainties). $C f$. infra notes 22-23 and accompanying text (discussing how distortions of legal principles can become generally accepted over time).

12. Prime brokerage is:

'a system developed by full-service [broker-dealer] firms to facilitate the clearance and settlement of securities trades for substantial retail and institutional investors who are active market participants.' . . . The prime broker [arranges] to clear and carry each trade placed by the customer when the customer directs delivery of money or securities to be made to or by the prime broker.... The customer maintains its funds and securities in an account with the prime broker. . . This arrangement is advantageous to prime brokerage customers because the prime broker acts as a clearing facility and accountant for all of the customer's security transactions wherever executed, as well as a central custodian for the customer's security and funds.

Isaac Lustgarten, De Facto Regulation of Hedge Funds through the Financial Services Industry and Protection against Systemic Risks Posed by Hedge Funds, 26 Banking \& Fin. Servs. PoL'Y ReP., Oct. 2007, at 1, 7-8 (2007) (quoting Bear Stearns, SEC No-Action Letter, 2 (Jan. 25, 1994)). Securities intermediaries can be either a clearing corporation or an entity, including a bank or broker, that in the ordinary course of its business maintains securities accounts for others and is acting in that capacity. U.C.C. $\S 8$-102(a)(14) (2009). Prime brokers are required to register as broker-dealers under Section 15(a) of the Securities Exchange Act of 1934. 15 U.S.C. $\S 78 \mathrm{o}(\mathrm{a})$ (2006).

13. See, e.g., U.C.C. $\S 8-504 \mathrm{cmt} .2$.

14. See infra note 74 and accompanying text (observing that rehypothecation has provided low-cost financing to the prime-brokerage business). Furthermore, the broker-dealers could use, and in many cases may well have used, the low-cost funding to enable their customers to finance the securities. Michael Huertas, Hedge Funds, Master Netting Arrangements and Rehypothecation: Limiting Systemic Risk Through Increased Transparency 3 (Working Paper Series, Apr. 20, 2009), available at http://ssrn.com/abstract=1411609 (observing that "[r]ehypothecation lowers the [prime broker's] costs of financing and some [prime brokers] pass 
customer securities become subject to claims of an intermediary's creditors, to whom the securities have been rehypothecated. If customer securities were to become subject to those claims, customers could lose their securities if the intermediary fails. This intermediary risk can motivate the intermediary's customers to withdraw their investments if they hear rumors of, or otherwise fear, an intermediary's insolvency. ${ }^{15}$

The most dramatic and consequential example of this occurred in the autumn of 2008. Thousands of customers, including many hedge funds, rushed to withdraw their investments from the accounts of Lehman Brothers, which had been acting as their prime-brokerage intermediary. ${ }^{16}$ Much like a "run on the banks" ${ }^{17}$, this rush to withdraw inadvertently triggered - or, at least significantly contributed to-Lehman's collapse. ${ }^{18}$ And Lehman's collapse was one of the central triggers of the worldwide financial crisis. $^{19}$

this cost saving to the [customer] in terms of lower borrowing costs, therefore undercutting traditional Bank lending").

15. One might ask how customers of an intermediary are able to withdraw their investments after rehypothecation occurs. There appear to be two answers. First, some of the customers' securities held by the intermediary may not yet have been rehypothecated. Second, to the extent customer securities have already been rehypothecated, customers will at least have a contractual claim against the intermediary for return of equivalent securities. See U.C.C. § 9-314 cmt. 3; Erica Johansson, Property Rights in InVestment SECURITIES AND THE DOCTRINE OF SPECIFICITY 148-49 (2009). Customers are unlikely to have any claim, however, against persons to whom the intermediary has rehypothecated the customers' securities. Compare U.C.C. § 9-623 (enabling a debtor to redeem its collateral at any time before a secured party has foreclosed thereon) with U.C.C. § 9-207 off. cmt. 5 \& 6 (indicating that the debtor's right in any such redeemed collateral will almost certainly be subordinate to the right of the party to whom the collateral was rehypothecated).

16. See, e.g., Michael King \& Philipp Maier, Hedge Funds and Financial Stability: Regulating Prime Brokers Will Mitigate Systemic Risks, 5 J. Fin. STABILITY 283, 290 (2009) (observing the magnitude of the panic, with hedge funds withdrawing their collateral and unwinding trades in advance of the failure of Lehman Brothers and the earlier failure of Bear Stearns); see also, Tom Cahill, Lehman Hedge Fund Client Left as Cold as Assets Frozen, BloOMBERG, Oct. 2008, http://www.bloomberg.com/apps/news?pid=20601109\&sid=adjHB.7sfLDA\&refer=home (observing that "clients yanked about 50 percent of Lehman's prime-brokerage assets in the week before the bankruptcy").

17. Lehman's inability to purchase and deliver the vast amount of equivalent securities demanded by its customers apparently led to its failure - just like a bank's inability to pay its depositors in a bank run can lead to the bank's failure. $C f$. Timothy Geithner, President and Chief Executive Officer, Fed. Res. Sys., Remarks at The Economic Club of New York, Reducing Systemic Risk in a Dynamic Financial System, (June 9, 2008) available at $\mathrm{http}: / / \mathrm{www}$.newyorkfed.org/newsevents/speeches/2008/tfg080609.html (observing that "[t]he scale of long-term risky and relatively illiquid assets financed by very short-term liabilities made many of the vehicles and institutions in this parallel financial system vulnerable to a classic type of run, but without the protections such as deposit insurance that the banking system has in place to reduce such risks").

18. See King \& Maier, supra note 16, at 289 (describing how the withdrawal of collateral by hedge funds and unwinding trades occurred in advance of the failure of Lehman Brothers). Professor Kettering argues that "even if [rehypothecation had not exposed Lehman's customers to intermediary risk], a rational investor would pull his securities out of a troubled intermediary, simply because of the risk that the securities won't prove to be there if the intermediary collapses." E-mail from Kenneth C. Kettering, Associate Professor of Law, New York Law School, to the author (Oct. 28, 2009, 20:20 EST) (on file with author). Customers of a deeply troubled intermediary may well take that view; but Lehman's customers began withdrawing their investments based only on rumors of instability, and the withdrawals themselves led to Lehman's collapse. Cf. Allan Sloan, A Year After Lehman, Wall Street's Acting Like Wall Street Again, WASH. PosT, Sept. 8, 2009, at A12 (stating that after the "bank run" on Lehman "[t]here was also the beginning of potentially catastrophic runs at Goldman Sachs and Morgan Stanley" by hedge funds that used these firms as prime brokers).

19. See, e.g., Adam Schell, Collapse Upended Economic Supports; Investment Bank's Failure Nearly 
This Article's analysis proceeds as follows. Part III uses rehypothecation, its distortion of nemo dat, and the resulting intermediary risk to construct a policy framework for assessing distortions of legal principles. Part IV tests and expands that framework by applying it to other distortions. Part V examines contexts in which individuals and institutions could apply the framework.

A threshold question is: what does this Article mean by "distortion of a legal principle"? The distinction between mandatory and default rules helps to inform the answer. By "legal principle," this Article means a normally mandatory rule or doctrine, such as the nemo dat rule, that is so generally accepted within a legal system that it forms a basis for reasoning. ${ }^{20}$ Distortion of a legal principle would occur when something distorts the principle in an unexpected way, creating uncertainty or confusion that undermines the basis for reasoning afforded by the principle. A distortion might occur, for example, if a normally mandatory legal rule were unexpectedly treated as a default rule.

The concept of distorting a legal principle also has temporal elements. For example, a long-standing distortion of a legal principle may become so generally accepted that it no longer distorts the principle in an unexpected way. ${ }^{21}$ Such a long-standing distortion would have trivial consequences, ultimately devolving into a mere exception to the principle. $^{22}$ Furthermore, the concept of distorting a legal principle refers to a legal

Triggered Meltdown, USA TODAY, Sept. 11, 2009, at 1B (observing that the collapse of Lehman Brothers triggered the following: "Almost 6 million lost jobs. A 5,000-point Dow plunge. The government bailing out cash-starved banks. General Motors and Chrysler declaring Chapter 11. The unemployment rate doubling to almost $10 \%$. Consumers getting $\$ 4,500$ handouts from Uncle Sam to buy a car. Talk of a 1930s-style depression"); Matthew Jaffe, Lessons to Be Learned One Year After Lehman Brothers Collapse Roiled the World, ABC NEws, Sept. 13, 2009, available at http://abcnews.go.com/Business/lessons-learned-year-financialcrisis-began/story?id=8563814; Nelson D. Schwartz, Crisis Began with Lehman's Collapse, Europeans Say, N.Y. TIMES, Oct. 10, 2008, available at http://www.nytimes.com/2008/10/10/business/worldbusiness/10ihteuro.4.16858400.html; Cf. Steven L. Schwarcz, Keynote Address: Understanding the Subprime Financial Crisis, 60 S.C. L. REV. 549, 552-53 (2009) (discussing how Lehman's failure transformed the subprime mortgage crisis into a more widespread financial panic); John H. Cochrane \& Luigi Zingales, Lehman and the Financial Crisis, WALL ST. J., Sept. 15, 2009, at A21 (arguing that although Lehman's failure did not by itself cause the financial crisis, it was "a movement in a dramatic crescendo of failures" that did).

20. Cf. OXFORD AM. Dictionary 530 (1980) (defining a "principle" as "a basic truth or a general law or doctrine that is used as a basis of reasoning ... "). This Article's conception of "generally accepted" legal principles does not mean a formally adopted set of rules and doctrines (such as the generally accepted accounting principles, or GAAP, promulgated in the United States by the Financial Accounting Standards Board, to be followed in financial accounting), merely rules and doctrines that are so generally accepted by society as to guide normal expectations.

21. See infra notes 57-72 and accompanying text (discussing long-standing distortions of nemo dat and other legal principles).

22. See id. In this context, one commentator asked whether the legal prohibition on yelling "fire" in a crowded theater should be viewed as a distortion of, or merely an exception to, the First Amendment principle of free speech. Although that example is beyond this Article's business context, I would view that long-standing legal prohibition as so universally known that it no longer distorts the free-speech principle in an unexpected way; thus, such prohibition has become less of a distortion and more of an exception to the legal principle. Another way of thinking about the distinction between a distortion and an exception is that a distortion would be a change in law that changes in an unexpected way a legal principle that is so generally accepted within a legal system as to form a basis for reasoning. See text accompanying supra note 20 (discussing "generally accepted" legal principles). An exception therefore would be a change in law that (i) does not change such a legal principle in an unexpected way or (ii) changes, whether or not in an unexpected way, a legal principle that 
principle at the time of the distortion. Legal principles can change, and indeed the centralized filing principle discussed in Part IV.A below exemplifies relatively recent change. ${ }^{23}$

There may be doubt at the margins as to what falls within these categories. Nonetheless, I believe that most would agree that the examples used in this Article are relatively clear in a business context. In that context, economic efficiency demands that parties be able to anticipate what is expected and assess the consequences. ${ }^{24}$

\section{REHYPOTHECATION AND INTERMEDIARY RISK}

\section{A. The Distortion}

Rehypothecation can distort the legal principle of nemo dat. An intermediary's granting of a security interest in securities that it owns would be conceptually clear and consistent with nemo dat: one may always grant a security interest in property (which, after all, is a "bundle of rights") ${ }^{25}$ to the extent of one's rights therein. ${ }^{26}$ The rehypothecation that occurred in Lehman's case, however, was different. ${ }^{27}$

Lehman, like many other prime-brokerage intermediaries, insisted that customers contractually consent to allow the intermediary to directly rehypothecate the customers' securities as collateral for financing obtained by the intermediary. ${ }^{28}$ Although this

is not so generally accepted within a legal system as to form a basis for reasoning.

23. Cf. infra notes 68-72 and accompanying text (discussing adapting to distortions).

24. See, e.g., Sharon Steel Corp. v. Chase Manhattan Bank, 691 F.2d 1039, 1048 (2d Cir. 1982) (explaining why "uniformity in interpretation is important to the efficiency of capital markets"); Sec. Nat'l Bank v. Dentsply Prof'1 Plan, 617 P.2d 1340, 1343 (Okla. 1980) (observing that "[a]lthough strict adherence to the [Uniform Commercial] Code requirements may at times lead to harsh results, efforts by courts to fashion equitable solutions for mitigation of hardships [caused by adherence to the literal text of the U.C.C.] may have the undesirable effect of reducing the degree of reliance the market place should be able to place on the Code provisions. The inevitable harm doubtless would be more serious to commerce than the occasional harshness from strict obedience"); Steven L. Schwarcz, A Fundamental Inquiry Into the Statutory Rulemaking Process of Private Legislatures, 29 GA. L. REV. 909, 923-31, 989 (1995) (discussing why certainty and clarity are fundamental commercial law requirements). For a discussion of efficiency as the goal of business and commercial law, see infra notes 40-47 and accompanying text.

25. See, e.g., Edward E. Chase, Property Law: Cases, Materials, and Questions 1 (2002) (observing that "property consists of a bundle of privileges, rights and duties with respect to things"). Cf. JOHANSSON, supra note 15, at 161, 166 (stating how the nature of an investor's rights is understood by considering securities entitlements as a bundle of rights, which means that the investor can only assert claims against its intermediary and bars the investor from the possibility of tracing the investment securities).

26. Cf. Jeanne L. Schroeder, Is Article 8 Finally Ready This Time? The Radical Reform of Secured Lending on Wall Street, 1994 COLUM. BuS. L. REV. 291, 468 (1994) (observing that when a "broker-dealer holds securities on behalf of customers and then purports to grant a perfected security interest in this customer property to a secured creditor[,] the secured party cannot get a greater interest in the securities than its debtor had, absent an applicable negotiability rule").

27. Anton R. VAlukas, Report of ANton R. VAlukas, Examiner in IN RE LeHMAN Brothers HoldiNGS INC. (Mar. 11, 2010), available at http://lehmanreport.jenner.com, does not address the issue of rehypothecation because its focus is limited primarily to identification of "colorable causes of action" and colorable claims for preferences or voidable transfers, $i d$. at 14-15, particularly those arising out of balancesheet manipulation of Lehman's "high-risk, high-leverage model that required the confidence of counterparties to sustain," $i d$. at 3,4-10. This Article does not suggest that rehypothecation, which was lawful at the time of Lehman's demise, would give rise to any colorable claims or causes of action.

28. See, e.g., Manmohan Singh \& James Aitken, Deleveraging after Lehman-Evidence from Reduced 
practice has been widespread and longstanding, ${ }^{29}$ it is conceptually flawed in that the intermediary does not own those securities but merely holds those securities on behalf of its customers, who at most give the intermediary a security interest in those securities. Lacking ownership of the customers' securities, the intermediary should not be able, under the principle of nemo dat, to grant a security interest that enables its creditors to obtain ownership of those securities through foreclosure. Conceptually, therefore, Lehman and other prime-brokerage intermediaries ignored nemo dat when engaging in this form of rehypothecation. ${ }^{30}$

\section{B. Consequences of the Distortion}

Rehypothecation has both positive and negative consequences. As discussed, it enables securities intermediaries to obtain low-cost financing. ${ }^{31}$ But its negative consequences (intermediary risk) have been devastating, including the failure of Lehman Brothers and the resulting worldwide financial crisis. ${ }^{32}$

At least in the United States, these consequences should have been mitigated - if not eliminated-by protections provided in commercial law, ${ }^{33}$ by a limitation on

Rehypothecation 3 (IMF Working Paper WP/09/42, 2009) (observing that, unless otherwise agreed, every prime-brokerage agreement includes a blanket consent to rehypothecation); e-mail from Lodewijk, Managing Director, Morgan Stanley, Legal and Compliance (London), to the author (Sept. 21, 2009, 04:45 EST) (on file with author) (observing that "UK [prime brokerage] clients were 'bullied' into accepting extensive re-use rights, and they accepted, [because] it gave them [very] low trading rates in return ..."). Cf. infra note 74 and accompanying text (observing that rehypothecation has been a less costly way of financing the prime-brokerage business than turning to other funding sources); Christian A. Johnson, Derivatives and Rehypothecation Failure: It's 3:00pm., Do You Know Where Your Collateral Is?, 39 ARIz. L. Rev. 949, 950-51 (1997) (observing that "[a]s part of an agreement to pledge collateral, dealers, banks, and other financial institutions participating in the derivatives market aggressively seek (and insist upon) the right to use posted collateral pledged to them").

29. Cf. The Rehypothecation Process, N.Y. TIMES, Jan. 1, 1878, at 4 (reporting on the collapse of two brokerage firms-Netter \& Co. and John Bonner \& Co.-resulting from these firms' rehypothecation of customer securities and commenting that "it is impossible to believe that we see the end of the rehypothecation business or of the shock it gives to all that remains of confidence in the Wall-street [sic] methods. What was supposed to be exceptional, if not accidental, turns out to be a system. The . . broker who adds to the plebeian brokerage the functions of . . money-lender[s], proves after all to be merely a borrower wearing a huge mask"); Greenleaf, Norris \& Co. Explaining the Rehypothecation of Securities-Nothing Irregular in the Transactions-A Defalcation Which Occurred in 1873, N.Y. TIMES, Mar. 5, 1878, at 8 (reporting the insolvency of Greenleaf, Norris \& Co. and how the firm mingled together its customers' securities and rehypothecated those securities to repay loans in the firm's name).

30. All further references in this Article to rehypothecation shall mean this form of rehypothecation - in which the broker-dealer or other intermediary directly pledges the customers' securities as collateral even though it does not own, but merely has a security interest in, those securities.

31. See supra note 14 and accompanying text (discussing financial securities).

32. Recall that rehypothecation's conceptual flaw causes uncertainty, which, in turn, creates intermediary risk. The flaw is that the intermediary, even though it does not own but at most has a security interest in its customers' securities, pledges those securities as collateral to creditors who expect to obtain ownership of those securities through foreclosure. The uncertainty and consequent intermediary risk concerns exposure of the customers' securities to claims of the intermediary's creditors to whom the securities have been rehypothecated, motivating the intermediary's customers to withdraw their investments if they hear rumors of, or otherwise fear, an intermediary's insolvency. See supra notes 14-18, 28-29 and accompanying text (discussing financial demise of firms).

33. See, e.g., Charles W. Mooney, Jr., Law and Systems for Intermediated Securities and the Relationship 
rehypothecation provided in securities law, ${ }^{34}$ and by government insurance of securities accounts (through the Securities Investor Protection Corporation, or "SIPC"). ${ }^{35}$ The commercial-law protections failed, however, because intermediaries had lobbied in the UCC revision process to exempt rehypothecated securities from those protections. ${ }^{36}$ The securities-law limitation failed because it was insufficient in amount to prevent customer "runs" from destroying intermediaries. ${ }^{37}$ The government insurance failed because its coverage was insufficient to prevent the panicked withdrawal by hedge-fund customers. ${ }^{38}$

of Private Property Law to Securities Clearance and Settlement: United States, Japan, and the UNIDROIT Draft Convention, Discussion Paper No. 2008-E-7, at 19 (2008) (describing how U.C.C. § 8-503(e) protects "any purchaser of a financial asset or interest therein who gives value, obtains control, and does not act in collusion with the securities intermediary in violating the securities intermediary's obligations" to maintain sufficient financial assets to cover an intermediary's entitlement holder claims to security entitlements).

34. In the United States, SEC Rule 15c3-3 (17 C.F.R. $§ 240.15$ c3-3 (2009)) limits the amount of securities held in margin accounts that may be rehypothecated. See also Cahill, supra note 16.

35. Mooney, supra note 33, at 16 (describing how the Securities Investor Protection Act, 15 U.S.C. $\S$ $78 \mathrm{fff}-3$ (a) (2006), protects account holders of insolvent broker-dealers against losses up to $\$ 500,000)$.

36. Cf. JOHANSSON, supra note 15, at 145-46 (stating that the predecessor section to U.C.C. § 9-207(c)(3) (i.e., former U.C.C. § 9-207(e)) required that the repledge not impair a debtor's right to redeem the collateral, but this qualification was removed in the Article 9 revision process to allow the secured party an extensive right to reuse the collateral). Johansson questions the accuracy of Official Comment 5 to U.C.C. § 9-207, which states that this change was made primarily for clarification: "there is no basis on which to draw any inference concerning the debtor's right to redeem the collateral." Indeed, that Comment acknowledges that a customer's right to redeem the collateral may not be enforceable against the new secured party because the secured party's right will be senior to the customer's interest. Cf. Kenneth C. Kettering, Repledge and Pre-Default Sale of Securities Collateral Under Revised Article 9, 74 CHI.-KENT L. REV. 1109, 1119-24 (1999) (arguing that U.C.C. 9-207(c)(3) places a burden on pledgors to negotiate a limitation on the secured party's now-unlimited statutory rehypothecation right).

37. Richard Johnston, Counterparty Risk-Where Do You Stand?, InV. \& Pensions AsiA, Jan. 26, 2009, available at http://www.ipe.com/asia/articleprint.php?id=30499. Cf. Thomas W. Joo, Who Watches the Watchers? The Securities Investor Protection Act, Investor Confidence, and the Subsidization of Failure, $72 \mathrm{~S}$. CAL. L. REV. 1071, 1110-11 (1999) (describing runs on broker-dealers as "a dramatic manifestation of the loss of investor confidence" that can be compared to the "contagious "bank runs' witnessed during the Great Depression" and observing that "[b]rokers worry . . . that failure of one big house could trigger a series of collapses in a sort of domino effect . . ."); Sec. Investor Prot. Corp. v. Barbour, 421 U.S. 412, 415, 421 (1975) (observing that although Congress's primary purpose in enacting the Securities Investor Protection Act (SIPA) was to protect investors, a secondary purpose was to prevent a domino effect of failing brokers: "the securities industry experienced a business contraction [in the 1960s] that led to the failure or instability of a significant number of brokerage firms. Customers of failed firms found their cash and securities on deposit either dissipated or tied up in lengthy bankruptcy proceedings. In addition to its disastrous effects on customer assets and investor confidence, this situation also threatened a 'domino effect' involving otherwise solvent brokers that had substantial open transactions with firms that failed. Congress enacted the SIPA to arrest this process, restore investor confidence in the capital markets, and upgrade the financial responsibility requirements for registered brokers and dealers.").

38. See, e.g., Madoff Investment Securities Fraud: Regulatory and Oversight Concerns and the Need for Reform: Hearing Before the S. Comm. On Banking, Housing and Urban Affairs, 111th Cong. 1, 7 (2009) (statement of Stephen P. Harbeck, President and CEO, Securities Investor Protection Corporation) (observing that "[b]ecause SIPA limits [to $\$ 500,000$ ] the maximum advance SIPC may make with respect to any one customer claim, the call upon SIPC's resources is limited," and that customers cannot even know, "[u]ntil all claims are filed, and forensic accounting completed," whether "SIPC's resources will be adequate"). See also Mary Pilon, Is the SIPC Sick?, WALL ST. J. BLOG, Jan. 30, 2009, http://blogs.wsj.com/wallet/2009/01/30/is-thesipc-sick/ (quoting testimony of Stephen Harbeck, President and CEO of SIPC, in January 2009 that after the failure of Lehman and Bernard Madoff "significant challenges" are in store for SIPC because "it cannot be 


\section{Towards a Framework for Balancing Consequences}

Should rehypothecation have been allowed to distort nemo dat in this way? Answering this question involves a balancing of the consequences of allowing, and disallowing, rehypothecation. ${ }^{39}$

\section{Balancing Consequences}

In a business context, consequences should be balanced to maximize efficiency. ${ }^{40}$ Economists generally measure efficiency by the Pareto and Kaldor-Hicks models. Pareto efficiency means that a transaction is efficient if it makes at least one person better off without harming others. ${ }^{41}$ In contrast, Kaldor-Hicks efficiency means that a transaction is efficient if its overall benefits exceed its overall harm, regardless of which parties are benefited and which are harmed. ${ }^{42}$ The Pareto efficiency model has few practical applications, and "it is pretty clear that the operating definition of efficiency in economics is not Pareto superiority." 43 Economists generally utilize the Kaldor-Hicks model when balancing consequences to maximize efficiency.

The widespread use of cost-benefit analysis can be viewed as a common-sense application of Kaldor-Hicks efficiency. In the United States, for example, before any regulatory agency can promulgate a major rule, it must deliver a cost-benefit analysis to Congress in which it attempts to monetize the benefits and costs of regulation, including any non-quantifiable factors that may affect the agency's decision. ${ }^{44}$ Regulation can be costly, so efficiency demands that its costs "do not exceed its benefits." 45 Government policymakers also use cost-benefit analyses when choosing between alternative options. ${ }^{46}$

However, a Kaldor-Hicks model of cost-benefit analysis may not be appropriate when analyzing the distortion of legal principles, even in a business context. Balancing

determined if SIPC's resources will be adequate' to cover" the losses suffered by brokerage clients). To provide additional insurance on customer deposits above SIPC's \$500,000 limit (and thereby attract customers), a consortium of brokers, including Lehman Brothers, had created Customer Asset Protection Company (Capco) in 2003. It does not appear, however, that customers were very comforted by Capco's coverage. $C f$. Zachery Kouwe, Billions in Lehman Claims Could Bury an Elusive Insurer, N.Y. TIMES, July, 31, 2009, at B1 (observing that "[b]y some industry estimates reviewed by the [New York State Insurance Department, Capco] could face nearly $\$ 11$ billion in claims but has only about $\$ 150$ million with which to meet them").

39. See generally Richard A. Posner, LAw, Pragmatism, AND Democracy (2003) (arguing that legal reasoning may not exist as an independent concept, and that what really matters is consequences).

40. $C f$. W. Kip Viscusi, John M. Vernon, \& Joseph E. HARrington, JR., ECONOMics of Regulation AND ANTITRUST 9 (3d ed. 2000) (arguing that, where health and safety are not at issue, the rationale for regulatory policy is "foster[ing] improvements judged in efficiency terms"); Gillian Hadfield, Privatizing Commercial Law: Lessons from the Middle and the Digital Ages 58-59 (Mar. 2000) (unpublished manuscript, available at http://papers.ssrn.com/sol3/delivery.cfm/000329600.pdf?abstractid=220252) (arguing that the "public value at stake in relationships between commercial entities . . . is economic efficiency").

41. Richard A. Posner, ECONOMiC ANAlysis of LAW § 1.2, at 13 (4th ed. 1992).

42. Id. $\S 1.2$, at $13-14$.

43. Id. $\S 1.2$, at 14 (discussing this "Kaldor-Hicks" standard as the operating standard of efficiency).

44. Steven L. Schwarcz, Systemic Risk, 97 GEO. L.J. 193, 234 (2008).

45. Id. at 210 .

46. Eric A. Posner, Controlling Agencies with Cost-Benefit Analysis: A Positive Political Theory Perspective, 68 U. CHI. L. REV. 1137, 1138-40 (2001); Matthew D. Adler \& Eric A. Posner, Implementing Cost-Benefit Analysis When Preferences Are Distorted, 29 J. LEGAL STUD. 1105, 1105 (2000). 
overall costs and benefits makes sense for assessing governmental actions that, at least theoretically, will be neutral as to any given group. But when parties take self-serving actions that could impose externalities on third parties (such as when they seek to distort legal principles for business ends) the impact should not be presumed to be inherently neutral. For example, even if the overall costs of rehypothecation exceed its benefits, some intermediaries may want to engage in rehypothecation because the allocation of its benefits and costs would apply differently to them. They would benefit directly from the lower cost financing afforded through rehypothecation whereas indirect costs, such as the costs of a systemic collapse of the financial system, would be spread among many. This is a type of tragedy of the commons: "the benefits of exploiting finite capital resources accrue to individual market participants... whereas the costs of exploitation, which affect the real economy, are distributed among an even wider class of persons," so market participants have insufficient incentive to internalize their externalities. ${ }^{47}$

\section{Adjusting the Balancing for Potential Bias}

In this potentially biased context, how-conceptually-should consequences be balanced? The Pareto model still appears unrealistic if we allow, as in the examples of this Article, that the distortions could be socially desirable. In a separate context, however, courts have wrestled with this same conceptual question.

Courts face this question when deciding whether to substantively consolidate separate corporate entities in bankruptcy 48 _a distortion of the legal principle of corporate separateness. ${ }^{49}$ In that context, courts grapple with balancing consequences where substantively consolidating those entities would maximize overall gain to creditors of the entities (which would be socially desirable under the Kaldor-Hicks model) at the cost of harming one or more creditors that extended credit in good faith on the integrity of the entity separateness (which would violate the Pareto model). The creditors favoring substantive consolidation argue for it solely in their own interests because such consolidation would improve their recovery at the cost of imposing an externality: lower recovery for creditors opposing such consolidation.

Although federal circuit courts are jurisprudentially split in this context, no such court has explicitly applied a simple positive balancing test. ${ }^{50}$ Some circuit courts apply a

47. Schwarcz, supra note 44, at 206. I call this a "type" of tragedy of the commons because it is not strictly a tragedy of the commons in which all parties involved commonly suffer the externality they cause.

48. Substantive consolidation is an equitable doctrine of bankruptcy law, arising under 11 U.S.C. $§ 105$ (2006), allowing a court under appropriate circumstances to consolidate the assets and liabilities of two or more separate companies if one of the companies is in bankruptcy. See, e.g., Sampsell v. Imperial Paper \& Color Corp., 313 U.S. 215 (1941) (consolidating the assets of a corporation with those of its shareholders); 5 WILLIAM MILLER COLLIER, COLLIER ON BANKRUPTCY 1100.06[3], at 1100-49, 51 (15th ed. 1989).

49. Even though a necessary yet insufficient condition for substantive consolidation is that a substantial identity exists between the entities being consolidated, as seen in In re Auto-Train Corp. v. Midland-Ross Corp., 810 F.2d 270, 276 (D.C. Cir. 1987), that does not obviate the fact that substantive consolidation distorts the legal principle of corporate separateness. This is because the "substantial identity" test under substantive consolidation law is insufficient to enable creditors to pierce the corporate veil under corporation law. Steven L. Schwarcz, Collapsing Corporate Structures: Resolving the Tension Between Form and Substance, 60 BuS. LAW. 109, 136-37 (2004).

50. Although In re Giller, 962 F.2d 796 (8th Cir. 1992) purports to follow cases that apply a "heavily outweigh" test, the language of In re Giller is somewhat ambiguous as to whether the Eighth Circuit is applying 
modified balancing test under which they will order consolidation only where its benefits "heavily outweigh" its harm. ${ }^{51}$ Implicitly, this test balances the consequences that selfserving creditors enjoy the benefits of the consolidation whereas innocent creditors are harmed. Three circuit courts, however, implicitly adhere to a Pareto, or do-no-harm, model. 52

Although I do not claim that substantive consolidation is - or should be-an exact precedent for the more general question of distorting legal principles, ${ }^{53} \mathrm{I}$ believe that its approaches provide insight for a normative analysis of that general question. If the distortion is not likely to be socially desirable, a do-no-harm test is clearly justified. But if, as with rehypothecation, the distortion may well be socially desirable, a balancing test is more appropriate. However, a simple positive balancing would introduce the potential for abuse where parties, by the distortions, impose externalities on third parties.

Because the parties enjoying the benefits are not necessarily the parties suffering the costs, a "heavily-outweigh" balancing test can help to rebalance the distributive effects. Furthermore, as this Article will illustrate, the consequences of distortions are difficult to anticipate and quantify; a heavily-outweigh test would require the benefits to be large in order to offset unknown or undervalued costs. ${ }^{54}$ The high burden of this test is also morally justified because any action that benefits certain parties at the cost of potentially seriously harming others is presumptively unjust, requiring a compelling justification. ${ }^{55}$ Moreover, a heavily-outweigh test is consistent with the "expected utility" approach to uncertainty often used by economists. This approach recognizes that people are not risk neutral, and thus costs and benefits should not be strictly compared. Instead, to reflect the reality of risk aversion, costs should be more heavily weighted than benefits in making

a "heavily outweigh" test or a simple positive balancing test.

51. In re Auto-Train Corp., 810 F.2d at 276; Eastgroup Props. v. S. Motel Ass'n, 935 F.2d 245, 249 (11th Cir. 1991). See also In re Lewellyn, 26 B.R. 246, 251 (Bankr. S.D. Iowa 1982) (stating that a creditor's reliance "should control consolidation unless it is clear that the economic prejudice of continued debtor individuality substantially outweighs the economic prejudice of consolidation").

52. In re Augie/Restivo Baking Co., 860 F.2d 515, 519 (2d Cir. 1988); In re Bonham, 229 F.3d 750, 766 (9th Cir. 2000); In re Owens Corning, 419 F.3d 195, 211 (3d Cir. 2005).

53. For example, substantive consolidation is an "equitable" remedy under $\S 105$ of the Bankruptcy Code, whereas the more general question of distorting legal principles does not necessarily involve bankruptcy law or the law of equity.

54. $C f$. Richard O. Zerbe JR., ECONOMIC EFFICIENCY IN LAW AND ECONOMICS 5-6, 8 (2001) (discussing the dichotomy between economic efficiency and distributional considerations and noting in particular that "[i]t was generally thought that by separating distributional considerations from aggregate gains a value-free measure would be obtained," but "[m] any critics of benefit-cost analysis have said that it ignores issues of income distribution and actual compensation, so that it approves a project that hurts those who should be helped, and benefits those who do not need it [and that it also] rests on faulty moral grounds, because it does not tell us the right thing to do ...") (emphasis added).

55. See Adler \& Posner, supra note 46, at 1110-11. Cf. Gregory C. Keating, Pressing Precaution Beyond the Point of Cost-Justification, 56 VAND. L. REV. 653, 671 (2003) ("Reducing risks of devastating injury beyond the point of maximal benefit (economically conceived) is justified when the potential gains are not morally comparable to the death or devastation that is their price. Reducing risks of devastating injury to the point where they are insignificant - the demand of safety-based regulation - is justified when the benefits of bearing a significant risk of devastating injury are not comparable, morally speaking, to the burdens.").

Cf. John E. Roemer, A Pragmatic Theory of Responsibility for the Egalitarian Planner, 22 PHIL. \& PUB. AFF. 146, 165-66 (1993) (observing that people will exercise different degrees of responsibility because (social and genetic) circumstances may force them to, and some will simply apply more effort than others). 
comparisons. ${ }^{56}$ Thus, a distortion of legal principles should be allowed only if its benefits would heavily outweigh its costs.

\section{Informing the Balancing Through Long-Standing Distortions}

The discussion below will test the merits of this heavily-outweigh balancing approach by applying it to rehypothecation. Before doing so, however, it is useful to examine whether areas of law where nemo dat has long been distorted might inform this approach. To this end, consider the commercial law rules governing holders in due course of instruments - that is, persons who take an instrument for value, in good faith, and without notice of a problem 57 - and buyers in the ordinary course of goods from merchants - that is, persons who buy goods from merchants in good faith and without notice of a problem. ${ }^{58}$ The former rules distort nemo dat by providing that a holder in due course of an instrument has the right to require the obligor thereunder to make payment notwithstanding certain defenses to payment that such obligor may assert against a prior holder of the instrument. ${ }^{59}$ The latter rules distort nemo dat by providing, for example, that an owner of goods who merely entrusts possession of the goods to a merchant who deals in goods of that kind gives the merchant the power to transfer good title to the goods to a buyer in the ordinary course of business, ${ }^{60}$ and that a buyer in ordinary course of goods takes free of any security interest in the goods that encumbers the seller's own right to the goods. 61

There are important policy reasons why these long-standing rules distort nemo dat. These rules achieve a measure of finality in commercial transfers of instruments to holders in due course and in sales of goods to buyers in the ordinary course by specifying that these transferees take title to these assets free and clear of most competing claims and defenses. ${ }^{62}$ That provides the clarity that transferees need to viably engage in the transactions. ${ }^{63}$ The rules also reduce transaction costs that might undermine the commercial viability of the transfers by reducing the need for these transferees to engage in due diligence regarding the possibility of any such competing claims or defenses. ${ }^{64}$

56. See Timothy O'Riordan \& JAMES CAMERON, INTERPRETING THE PRECAUTIONARY PRINCIPLE 13235 (1994).

57. U.C.C. § 3-302(a) (2002). Instruments include, among other things, checks, promissory notes, and negotiable securities. Id. $\S 3-103$.

58. Id. $\S 1-201(\mathrm{~b})(9)$.

59. Id. $\S 3-305(\mathrm{~b})$.

60. Id. $\S 2-403(2)$.

61. U.C.C. $\$ 9-320(a)(2002)$.

62. Id. § 3-306 (2000); id. § 3-305(b); id. §§ 2-403(1)-(2).

63. See, e.g., Gregory E. Maggs, The Holder in Due Course Doctrine as a Default Rule, 32 GA. L. REV. 783, 792 (1998) (“A party contemplating buying a negotiable instrument or taking one in payment from someone other than its maker may have two concerns relating to his or her right to enforce the instrument. One is that the maker will have a legal ground for refusing to pay. The other is that someone else will claim ownership of the instrument. The party taking the instrument, in theory, could address both these worries by expending time and money to investigate the origin of the negotiable instrument before purchasing it or taking it in payment. The holder in due course doctrine, however, makes that effort largely unnecessary by stripping away claims of ownership and most defenses. The doctrine, therefore, arguably encourages parties to take negotiable instruments when they would otherwise hesitate.").

64. Id. See also id. at 813-14 (observing that the holder-in-due-course rule "saves transaction costs and promotes efficiency"). 
Thus, although these rules sometimes may harm third parties - for example, third parties may not assert otherwise valid claims or defenses on the transferred instruments or goods - the benefits achieved by distorting nemo dat under the rules appear to at least outweigh, and perhaps heavily outweigh, the costs of the distortion. On its face, though, a factual inquiry as to the degree by which those benefits outweigh those costs would not inform this Article's normative analysis because the existence of positive law does not necessarily inform what the law should be ${ }^{65}$ History alone should not sufficiently justify these distortions to nemo dat.

The long-standing existence of these rules, and thus of these distortions, nonetheless suggests a normative insight: the very fact these distortions are long-standing makes them more likely than recent distortions to generate benefits that heavily outweigh their costs. This is because whether or not the benefits of these distortions originally heavily outweighed their costs the distortions are now so ingrained in commercial law that third parties should be aware of their impact; thus, they should structure their transactions accordingly. In other words, the nemo dat principle is no longer distorted by these distortions in an unexpected way. ${ }^{66}$

For example, lenders secured by a merchant-borrower's inventory would no longer contemplate the possibility, assuming the merchant defaults in repayment, of proceeding against inventory sold by the merchant to its customers. Instead, lenders will make other arrangements - arrangements that themselves may be enabled by an evolution of law in response to the rules - to protect their rights to repayment, such as monitoring and controlling cash receipts from the merchant's inventory sales. ${ }^{67}$ Over time, the costs imposed by distortions of legal principles can diminish as third parties adapt and the law evolves to accommodate the adaptations.

Accordingly, to the extent a legal system is flexible enough to cope over time with a distortion of legal principles, ${ }^{68}$ a complete balancing of costs and benefits of the distortion should theoretically take into account the costs of adapting to the distortion and the reduction in distortion costs as such adaption occurs. In practice, though, these changing adaptation costs would be hard to measure. Any adaptation would likely require a long transition period, ${ }^{69}$ and it would be difficult to quantify the adaptation costs during such a period. It also is possible that adaption will never be fully achieved for some distortions. Indeed, even though rehypothecation has been widespread and longstanding

65. Cf. Alan Schwartz \& Robert E. Scott, Commercial Transactions: Principles and Policies 18 (2d ed. 1991) (contending that "“oughts' cannot be derived from 'what is"”) (citing G.E. MoORE, PRINCIPIA ETHICA 10-14 (1971)).

66. See supra notes 20-23 and accompanying text (defining a "distortion" as something that would distort a legal principle in an unexpected way).

67. See Harley-Davidson Motor Co. v. Bank of New England, 897 F.2d 611, 613-14 (1st Cir. 1990) (in which Old Colony Bank controlled motorcycle title certificates for this purpose).

68. Common-law systems may be especially adaptable in this regard given their ability to evolve through judicial decisions and scholarly commentary.

69. One reason the adaption period may be lengthy is that most commercial litigation, especially between financial institutions, is settled, so few judicial decisions are actually reached. Cf. Stephanie Plancich \& Svetlana Starykh, Recent Trends in Securities Class Action Litigation: 2009 Year-End Update, 13 (Dec. 2009) available at http://www.nera.com/image/Recent_Trends_Report_1209.pdf (observing that "historically more securities class action cases resolve in settlement than in dismissal or verdict"). 
for well over a century, ${ }^{70}$ the law has not yet adequately coped with its uncertainties. ${ }^{71}$ Because these adaptation costs are likely to be much lower than direct costs, this Article will treat them as relatively insignificant for computational purposes (although it will refer to them as applicable). ${ }^{72}$

This Part therefore concludes that the consequences-i.e., the costs, including the costs of distorting nemo dat, and the benefits-of allowing or disallowing rehypothecation should be balanced under a heavily-outweigh test.

\section{Applying the Framework}

In order to apply the heavily-outweigh balancing test, one needs to identify and quantify the costs and benefits of allowing rehypothecation. First, consider benefits. Rehypothecation certainly has been important to the economy, to securities intermediaries and their customers, and to the prime-brokerage business. Some have observed, for example, that the prime-brokerage business was "built on [the] practice known as rehypothecation."73 Historically, rehypothecation has been a less costly way of financing the prime-brokerage business than turning to other funding sources. ${ }^{74}$ Indeed, the sudden drop in rehypothecation in response to Lehman's failure resulted in higher funding costs for financial institutions ${ }^{75}$ and possibly reduced liquidity. ${ }^{76}$ These higher funding costs have been loosely estimated at between 90 and 240 basis points. ${ }^{77}$

Moreover, it appears that rehypothecation is likely to be important to financial institutions in the future. There is evidence that significant rehypothecation may be taking place a year after Lehman's failure, ${ }^{78}$ even though the absolute amount has not quite

70. See supra note 29 and accompanying text (discussing rehypothecation in firms).

71. See supra notes 33-38 and accompanying text (discussing how rules and regulations should have mitigated the negative financial consequences).

72. See, e.g., infra note 117 (discussing buyer adaptation to the uncertainties caused by automatic perfection of sales of payment intangibles).

73. James Mackintosh, Collapse of Lehman Leaves Prime Broker Model in Question, FIN. TIMES (London), Sept. 25, 2008, at 47 (observing that Lehman's European prime-brokerage arm rehypothecated \$22 billion of the $\$ 40$ billion customer securities it held).

74. Singh \& Aitken, supra note 28 , at 3 n. 3. See also Johnson, supra note 28, at 969 ("The primary rationale driving rehypothecation appears to be that it provides dealers with an inexpensive source of financing ....").

75. Singh \& Aitken, supra note 28, at 7. After Lehman's failure, many hedge funds have been choosing not to allow their collateral to be rehypothecated (by requiring prime brokers to use segregated accounts or triparty custodian arrangements) or have been diversifying (from using one to multiple prime brokers). See, e.g., Manmohan Singh \& James Aitken, Counterparty Risk, Impact on Collateral Flows, and Role for Central Counterparties, 8 (Int'l Monetary Fund Working Paper WP/09/173, 2009) (reporting reduced collateral postings of large financial firms); Mackintosh, supra note 73 (stating that Lehman's collapse and the resultant concerns over the stability of Morgan Stanley and Goldman Sachs caused many hedge funds to shift money out of Morgan and Goldman into the prime brokerages of commercial banks regarded as safer and also caused more jittery hedge funds to stop borrowing and move their assets to custodian accounts).

76. Singh \& Aitken, supra note 28 , at 7 .

77. See Mackintosh, supra note 73 (noting that, though the cost increase is difficult to determine, brokers estimated as of Sept. 25, 2008 that London and Wall Street banks' cost of internal financing absent rehypothecation was approximately 150-300 basis points over LIBOR, compared with 60 basis points over LIBOR for rehypothecated assets). A basis point equals one-hundredth of one percent; therefore, the references to 90 basis points and 240 basis points mean, respectively, $0.9 \%$ and $2.4 \%$.

78. Matthew Goldstein, Wall Street's \$4 Trillion Kitty, REUTERs NEws, Aug. 24, 2009. 
rebounded to pre-Lehman levels. ${ }^{79}$ The reemergence of rehypothecation is not surprising, since attempts by customers (such as hedge funds) "to diversify counterparty risk and [protect] their collateral [through] third part[y] [custodians] ... increase complexity and costs for hedge funds, while not necessarily reducing risk and at the same time making business harder for prime brokers." 80 Thus, although a precise numerical measure of the benefits of rehypothecation is not feasible, the range appears to be on the order of billions of dollars per year. ${ }^{81}$

Next consider the costs of allowing rehypothecation. As discussed, rehypothecation's distortion of nemo dat creates uncertainty whether customer securities are subject to claims of the intermediary's creditors to whom the securities have been rehypothecated, resulting in intermediary risk that can motivate the intermediary's customers to withdraw their investments if they hear rumors of, or otherwise fear, an intermediary's insolvency. ${ }^{82}$ Such withdrawal, in turn, could cause the intermediary to collapse or even help to trigger a broader financial meltdown. ${ }^{83}$

These costs could conceivably be huge. For example, the recent financial crisis has been estimated to have cost the United States alone at least tens of trillions of dollars. ${ }^{84}$ If rehypothecation increases the chance of another financial meltdown by even a few percent per year, the cost would be staggering. And this cost would not even include the cost of rehypothecation causing one or more intermediaries to collapse without triggering a broader systemic effect.

In the context of rehypothecation, however, these costs cannot be reliably estimated because of the difficulty in knowing ex ante the probability that the distortions caused by rehypothecation will cause these consequences. Without more, one cannot determine whether the benefits of allowing rehypothecation heavily outweigh its costs. ${ }^{85}$ This calculus nonetheless can be informed by the "precautionary principle," often used by regulators applying cost-benefit analysis to address the cost of catastrophic events or large, irreversible effects where the actual level of risk is indeterminate. ${ }^{86}$ This principle

79. See, e.g., Karen Brettell, Debt Costs to Rise as Bank Collateral Re-use Falls, REUTERS, Sept. 21, 2009, available at http://www.reuters.com/article/ousivMolt/idUSTRE58K4I020090921 (stating that the amount of customer securities that Goldman Sachs was allowed to repledge fell from $\$ 891$ billion in November 2007 to $\$ 596$ billion in June 2009 and that the amount of customer securities that Morgan Stanley could repledge fell from $\$ 948$ billion in November 2007 to $\$ 331$ billion in June 2009).

80. Josh Friedlander, Heavy Lifting Ahead, Absolute Return Mag., April 2009, at 4.

81. I reach this estimate as follows: the interest-rate cost saving from rehypothecation has been "loosely estimated" as between 90 and 240 basis points, supra note 77, and the level of rehypothecation appears to be in the range of at least a trillion dollars or more, supra note 79. Assuming that intermediaries, absent rehypothecation, would still need roughly the same amount of funding, rehypothecation would generate a cost savings of at least $0.9 \%$ per annum on at least $\$ 1$ trillion, yielding a yearly saving of at least $\$ 9$ billion.

82. See supra notes 14-15 and accompanying text (discussing intermediary's insolvency).

83. See supra notes 16-19 and accompanying text (explaining how clients' reactions led to the meltdown).

84. Total Cost of World Financial Crisis at \$11.9 th: IMF, ECON. TIMES, Aug. 9, 2009, available at $\mathrm{http}$ //economictimes.indiatimes.com/News/International-Business/Total-cost-of-world-financial-crisis-at-119tn-IMF/articleshow/4874366.cms.

85. For a more quantitatively determinable example of whether the benefits of allowing a distortion would heavily outweigh its costs, see infra Part IV.A.

86. See Cass R. Sunstein, Irreversible and Catastrophic, 91 CoRNELl L. REV. 841, 849 (2006) (describing various applications of the precautionary principle); JAMES SALZMAN \& BARTON H. THOMPSON, JR., Environmental LaW And Policy 16 (2d ed. 2007); Robert G. Chambers \& Tigran A. Melkonyan, Pareto 
presumes that the benefits of restricting the risk through regulation will exceed the costs. ${ }^{87}$ In the principle's most utilized form, ${ }^{88}$ regulators may decide to regulate an activity notwithstanding a lack of decisive evidence of the activity's harm. ${ }^{89}$

Rehypothecation would fit within the scope of the precautionary principle, since allowing rehypothecation would perpetuate the risk of a catastrophic event-another systemic collapse of the financial system-whereas the actual level of risk is indeterminate. To this extent, it may well be appropriate to presume that the benefits of allowing rehypothecation will not heavily exceed the costs. Under this Article's framework for assessing distortions of legal principles, rehypothecation should therefore not be allowed, or at least should be regulated.

Although disallowing rehypothecation would be a harsh result, it would encourage parties to explore possible ways of engaging in rehypothecation that could mitigate its costs (uncertainty resulting from distortion) but preserve its benefits (lower funding costs). ${ }^{90}$ For example, instead of a prime broker or other intermediary rehypothecating customers' securities that it does not own, perhaps the intermediary should "rehypothecate" only its right to receive payments from those customers. Because the intermediary's right to receive those payments is secured by the customers' securities, a lender to the intermediary would be able to look to those securities as indirect collateral; thus, lenders secured in this manner would be expected to continue lending to prime brokers and other intermediaries at reasonably advantageous interest rates. ${ }^{91}$ Furthermore, the customers' securities would not be directly exposed to claims of the intermediary's creditors $^{92}$ - an exposure that created the intermediary risk that motivated

Optimal Trade in an Uncertain World: GMOs and the Precautionary Principle, 89 AM. J. AgRIC. ECON. 520, 528 (2007).

87. Although this principle is often explicitly mentioned in international environmental regulations, it is also implicit in certain domestic regulations such as those concerning efforts to prevent terrorist attacks or regulation of the nuclear power industry, where high costs are justified even in the face of uncertain risk. See Cass R. Sunstein, Beyond the Precautionary Principle, 151 U. PA. L. REV. 1003, 1005-07 (2003).

88. Cf. Daniel Bodansky, Deconstructing the Precautionary Principle, in BRINGING NEW LAW TO OCEAN WATERS 381 (David D. Caron \& Harry N. Scheiber eds., 2004) (discussing the many different meanings and potential applications of the precautionary principle).

89. Id. at 381, 383-84 (describing this approach as the "most common formulation of the precautionary principle"). See also Sunstein, supra note 87, at 1017-18 (discussing, among other things, controlling low-level exposure to carcinogens notwithstanding lack of proof of a causal connection between such exposure and adverse effects to human health). Governments have incorporated this principle into regulatory policies, and the European Commission has urged that the precautionary principle be considered within a structured approach to the analysis of risk. $I d$.

90. Cf. Ian Ayres \& Robert Gertner, Filling Gaps in Incomplete Contracts: An Economic Theory of Default Rules, 99 YALE L.J. 87, 115 n. 122 (1989) (arguing that if "no well-established default exists, many contracting parties may explicitly contract for what they want").

91. E-mail from Shami Patel, former investment banker involved in rehypothecation, to the author (Dec. 17, 2009, 11:25 EST) (on file with author). This Article does not claim that those interest rates would necessarily be as low as under traditional rehypothecation lending, merely that they should be more advantageous than rates lenders to intermediaries would charge absent the modified rehypothecation proposal discussed above.

92. To understand why the customers' securities would not be directly exposed to claims of the intermediary's creditors, consider the rights of such a creditor. A lender to the intermediary secured by the intermediary's right to receive payments from its customers - a right that already is secured by the customers' securities - could attempt to foreclose on its collateral if the intermediary defaults in repaying the loan. After 


\section{Lehman's customers to withdraw their investments. ${ }^{93}$}

This Article does not claim that rehypothecation should necessarily be disallowed. The precautionary principle and its application to rehypothecation within this Article's framework are merely approaches that regulators could consider utilizing. These approaches also provide a useful way of thinking about whether to allow the distortion of legal principles caused by rehypothecation and about potential lower-cost alternatives.

\section{OTHER DISTORTIONS AND THEIR CONSEQUENCES}

The analysis above used rehypothecation and its distortion of nemo dat as a basis for constructing a framework to assess distortions of legal principles. Under the framework, a distortion should be allowed only where its benefits would heavily outweigh its costs. The discussion also considered a precautionary principle, under which it would be presumed that the benefits of distortions that create an indeterminate risk of catastrophic events would not heavily exceed the costs. Although disallowing such a distortion might be viewed as a harsh result, it would encourage parties to explore lower-cost alternatives for achieving the business benefits otherwise attainable through the distortion. Part IV tests and expands on that framework by applying it to other distortions of legal principles.

\section{A. Automatic Perfection}

In commercial law, the legal principle of "perfection" fundamentally requires that third parties be put on notice of transfers of intangible rights in order to make such transfers enforceable. ${ }^{94}$ The rationale is to avoid so-called "secret" liens, which could defraud creditors. ${ }^{95}$ Under modern commercial law, third parties are normally put on notice of these transfers through registration systems. In the United States, notice occurs

foreclosure, the lender would have the right to demand payment from those customers and, additionally, to foreclose in turn on the securities of customers who failed to pay. See U.C.C. §§ 9-607 to 9-608 (2002) (outlining the collection and enforcement procedure). However, customers could prevent that second foreclosure - on their securities - merely by paying the lender the amounts they already owe to the intermediary. Id. Such payment would extinguish their obligations to pay those amounts to the intermediary, so customers would not be subject to the risk of double payment. Id. §9-406(a).

93. Supra notes 15-16 and accompanying text. There may well be other possible ways of engaging in rehypothecation that could mitigate its costs but preserve its benefits. Even without changing how rehypothecation works, for example, SIPC insurance could be increased in amount and scope or other FDIClike protection of securities accounts could be implemented to ensure customer protection. See supra notes 3338 and accompanying text (discussing SIPC insurance). In that scenario, however, the costs of paying for this increased protection, which likely would be borne by intermediaries and their customers, would have to be subtracted from the benefits. Cf. Evan Cooper, SIPC Raises Assessment Fees on Brokerage Firms, INV. NEWS, Mar. 3, 2009, http://www.investmentnews.com/article/20090303/FREE/903039997 (describing how the SIPC raised assessment fees for member brokerage firms from a flat yearly fee of $\$ 150$ to $0.25 \%$ of net operating revenue, effective April 1, 2009, in order to address the Madoff fraud and other losses). Alternatively or in addition, the limitation on rehypothecation provided in securities law could be increased to a level that would be more likely to prevent customer "runs" from destroying intermediaries. See supra notes 33-38 and accompanying text (arguing that exempting rehypothecated securities rendered the limitations unable to prevent customer "runs").

94. See, e.g., U.C.C. § 9-205 cmt. 2 (2008).

95. Benedict v. Ratner, 268 U.S. 353, 360, 363-65 (1925). 
through the filing of financing statements under the Uniform Commercial Code (UCC). ${ }^{96}$ Banks have lobbied, however, to exempt sales of "payment intangibles" — certain rights to payment of money97_from the UCC's filing requirement. Banks asserted (although arguably incorrectly) ${ }^{98}$ that this exemption was needed to make it no more burdensome and costly than under pre-UCC law to diversify lending risk through the sale of loan participations. ${ }^{99}$ As a result of this lobbying, the UCC provides that sales of payment intangibles are automatically perfected without the filing of financing statements. ${ }^{100}$

This is a distortion of a legal principle because it is directly and unexpectedly inconsistent with the generally accepted rule that perfection requires some form of thirdparty notice. As the discussion below shows, this distortion has so undermined how parties reason about perfection that it has created uncertainty and confusion.

For example, a buyer of intangible rights who believes, mistakenly, that the sale is automatically perfected will lose ownership of those rights if the seller goes bankrupt. ${ }^{101}$ For example, in In re Commercial Money Center, the intangible rights at issue consisted of rights to payment of certain lease installments. ${ }^{102}$ NetBank, the buyer (ironically, a bank), believed the intangible rights were payment intangibles. ${ }^{103}$ The seller, Commercial Money Center, argued in bankruptcy that those rights were not payment intangibles, and therefore their sale was not automatically perfected. ${ }^{104}$ The bankruptcy court ruled that the intangible rights were not payment intangibles. ${ }^{105}$ NetBank, which had not filed financing statements, was unperfected, and its $\$ 47$ million purchase was therefore avoided. ${ }^{106}$

Another negative consequence is that automatic perfection makes it difficult, if not impossible, to know one's priority in purchased payment intangibles. Because there is no filing, a buyer of payment intangibles must take the seller's word that such intangibles have not been previously sold. If the sale is dishonest, or even if the seller is merely

96. U.C.C. § 9-310(a) (2008). The UCC governs certain sales of intangible rights to "avoid[] difficult problems of distinguishing between transactions in which a receivable secures an obligation and those in which the receivable has been sold outright[,]" since in "many commercial financing transactions the distinction [between these transactions] is blurred." Id. $\S 9-109 \mathrm{cmt}$. 4. Another reason the UCC governs those sales is to apply Article 9's perfection and priority system to protect purchasers in those sales.

97. Payment intangibles are rights to payment of money which do not fall into certain categories. Id. § 9102(a)(61).

98. See Steven L. Schwarcz, Automatic Perfection of Sales of Payment Intangibles: A Trap for the Unwary, 68 Oніо ST. L.J. 273, 277-78 [hereinafter Automatic Perfection of Sales] (explaining why a UCC requirement to file financing statements for perfection would not be more burdensome than pre-UCC requirements).

99. Loan participations are a form of intangible payment consisting of undivided interests in loans. See Intermediary Risk in a Global Economy, supra note 7, at 1557-61 (discussing the sale of loan participations).

100. U.C.C. §9-309(3) (2008).

101. See Automatic Perfection of Sales, supra note 98, at 274-75 (explaining how this can occur).

102. In re Commercial Money Center, Inc., No. 02-09721-H7, 03-90331-H7, 2005 Westlaw 1365055, at*1 (Bankr. S.D. Cal.).

103. Id. at $* 2$.

104. Id.

105. Id. at $* 11$.

106. Id.; Automatic Perfection of Sales, supra note 98, at 275. The In re Commercial Money Center, Inc. case was appealed, first to a federal district court and then to the Ninth Circuit's Bankruptcy Appellate Panel, which ultimately ruled that NetBank's interest was unperfected. In re Commercial Money Center, Inc., 392 B.R. 814 (B.A.P. 9th Cir. 2008). 
mistaken about the existence of a prior sale, the subsequent buyer's ownership interest would be subordinate to the rights of prior automatically perfected buyers. The inability to know ownership priority undermines the market for selling intangible rights and increases costs where sales do occur. ${ }^{107}$

Consider how this Article's framework would apply to automatic perfection of sales of payment intangibles. The benefit of such automatic perfection is that bank sales of payment intangibles in the form of loan participations, which are critical to enabling them to diversify lending risk, can be safely accomplished without the transaction costs of having to file financing statements for each such sale. In the United States, for example, banks collectively sell perhaps tens of thousands of loan participations daily, ${ }^{108}$ which I will conservatively round up to a hundred thousand daily sales. The average cost per filing is $\$ 17.34,{ }^{109}$ which I will conservatively round up to $\$ 20$. There are approximately 249 business days for banks each year. ${ }^{110}$ Thus the yearly benefit to banks might be in an order of magnitude as much as half a billion dollars a year. ${ }^{111}$

Next, consider the costs of allowing automatic perfection. As discussed, the uncertainty this distortion causes creates serious negative consequences: buyers of intangible rights who believe, mistakenly, that their purchase is automatically perfected will-like NetBank, which lost $\$ 47$ million-lose ownership of those rights if the seller goes bankrupt. Even buyers who are perfected cannot know their priority in purchased payment intangibles, thereby undermining the market for selling intangible rights and increasing costs when sales do occur. The latter costs (resulting from inability to know priority) can be reasonably estimated from empirical studies of nations without centralized registration systems for perfection - the absence of centralized registration

107. Steven L. Schwarcz, Towards a Centralized Perfection System for Cross-Border Receivables Financing, 20 U. PENN. J. INT'L ECON. L. 455, 462-69 [hereinafter Towards a Centralized Perfection System] (examining the difficulty of knowing priority absent a filing system, and the high cost of not knowing priority).

108. Cf. U.S. Secondary Loan Market Volume, Thomson Reuters LPC Traders Survey, available at $\mathrm{http} / /$ www.loanpricing.com/analysis/volume.php (reporting that the market volume for secondary loans in 2008 was $\$ 318.38$ billion); A. Gande \& A. Saunders, Are Banks Still Special When There is a Secondary Market for Loans? 8, (Working Paper, 2009), available at http://ssrn.com/abstract=873353 (finding that loan participations are sold extensively by observing that the volume of trading in the secondary loan market exceeded $\$ 100$ billion per year in 2000 and reached a peak of \$342.02 billion in 2007); Gary B. Gorton \& Joseph G. Haubrich, The Loan Sales Market 6, (White Center for Financial Research Working Papers No. 35-88, Sept. 1988), available at http://finance.wharton.upenn.edu/ rlwctr/papers/8835.PDF ("The volume of loan sales [secondary loan participations] has grown from an almost insignificant amount in the late 1970s to $\$ 236.3$ billion in the first quarter of $1988 \ldots . .$. . $)$.

109. I use an average cost because each state charges a different fee for filing UCC-1 financing statements (some states charge as low as \$3 per filing and others as high as $\$ 84$ per filing). See Spreadsheet prepared by Sean MacGregor (Jan. 22, 2010) (on file with author) (containing filing information indexed by state, filing fee, and source of information, and calculating the average filing cost). Cf. Lynn M. LoPucki, Commentary on Professor White's Article: The Article 9 Filing System: Why the Debtor's State of Incorporation Should be the Proper Place for Article 9 Filing: A Systems Analysis, 79 MINN. L. REV. 577, 644-45 (1995) (determining that the range of filing fees for financing statements in 1994 “was $\$ 3$ to $\$ 25$, and the average was $\$ 10.43$ ”).

110. I calculate this as follows: ( 52 weeks/year $\mathrm{x} 5$ days/week $)-11$ federal holidays $=249$.

111. I calculate this as follows: 100,000 filings/day x $\$ 20 /$ filing x 249 days $=\$ 498$ million. One reviewer of this article suggests, however, that this number leaves out the cost of preparing financing statements, which "is likely to at least equal the cost of the filing fee." E-mail from Paul Shupack, Professor of Law, Benjamin N. Cardozo School of Law, to the author (Dec. 23, 2009, 12:01 EST) (on file with author). 
being equivalent, for these purposes, to automatic perfection. ${ }^{112}$ These studies have found that, at least for certain non-OECD nations, ${ }^{113}$ the inability to know one's priority can add as much as $20-30$ percentage points to financing rates. ${ }^{114}$ Clearly these numbers would be much lower in a developed country such as the United States, but even if one estimates them at only 20-30 basis points, a mere hundredth of these findings, ${ }^{115}$ the economic cost would be huge and may well even exceed the benefits of automatic perfection. ${ }^{116}$ To that economic cost one must also add the costs suffered by buyers of intangible rights when they believe, mistakenly, that their purchase is automatically perfected (although those costs, while real, are harder to estimate because the number of buyers that lose money in this way, or the amounts of money they lose, is unknown). ${ }^{117}$

On balance, therefore, it appears that the benefits of allowing automatic perfection might or might not outweigh, but are unlikely to heavily outweigh, the costs. ${ }^{118}$ Thus, under this Article's framework, automatic perfection should be disallowed. ${ }^{119}$ This result must be tempered, however, by the caveat that a quantitative analysis is no better than its assumptions and data. The result should therefore be interpreted cautiously. All that can be said with confidence is that the distortion that automatic perfection causes should be allowed only when its benefits truly heavily outweigh its costs. This nonetheless provides a useful way of thinking about the problem of whether or not to allow the distortion.

112. Towards a Centralized Perfection System, supra note 107, at 463-64.

113. The OECD, or Organisation for Economic Co-operation and Development, generally represents highincome countries with developed economies. See, e.g., OECD Annual Report 2009, at 6-7, available at http://www.oecd.org/dataoecd/38/39/43125523.pdf (last visited Jan. 18, 2010).

114. Towards a Centralized Perfection System, supra note 107, at 467-68.

115. Recall that a basis point equals one-hundredth of one percent. Supra note 77 and accompanying text.

116. For example, if the priority-uncertainty rate increase averaged 25 basis points per annum, the resulting yearly cost increase would exceed $\$ 1$ billion (the estimated yearly benefit from automatic perfection) if there were at least $\$ 400$ billion of yearly sales of payment intangibles.

117. One might argue that NetBank's disaster was highly publicized, putting potential buyers of payment intangibles on notice of this risk. In the future, therefore, buyers of payment intangibles could adapt by filing financing statements if there is any uncertainty as to whether the rights they are buying are in fact payment intangibles. The cost of that adaptation, however, may well equal if not exceed the cost banks avoid when they avoid filing financing statements because there is substantial intrinsic uncertainty as to whether any given right to payment constitutes a payment intangible. Automatic Perfection of Sales, supra note 98 (discussing the intrinsic uncertainty); $i d$. at 276 (observing that "any widespread practice of prophylactic filing for sales of intangible rights could amount to roughly the same filing costs and burdens as simply requiring such filing" for sales of payment intangibles). Moreover, buyers of automatically-perfected payment intangibles could not adapt to their inability to know their priority in purchased payment intangibles, and so those uncertainty costs would continue. Id. at 276 .

118. This result would of course be even more obvious if, as I have argued, the UCC requirement to file financing statements for perfection would not be more burdensome on banks selling loan participations than under pre-UCC requirements. See Automatic Perfection of Sales, supra note 98 (arguing that the UCC requirement would not be more burdensome).

119. One might question whether a heavily-outweigh test should be applied to the question of automatic perfection since this distortion was legislatively enacted. I believe that test is appropriate for any balancing of costs and benefits for distortions that are intended to benefit only specific groups - in this case, the banks. $C f$. supra notes 46-47 and accompanying text (indicating that a simple positive balancing test may be appropriate for government actions that "theoretically will be neutral as to any given group"). 


\section{B. Priority Reversal for Minerals}

One of the most fundamental legal principles of commercial law, underpinning the importance of preserving commercial expectations, ${ }^{120}$ is that a person who has a first priority claim in an asset should not involuntarily lose that priority. In the secured transactions context, that principle is embodied in the first-in-time, first-in-right rule of the Uniform Commercial Code. ${ }^{121}$ Although there is an exception to that rule for a limited class of purchase-money security interests, ${ }^{122}$ that exception is longstanding, ${ }^{123}$ has important policy rationales, ${ }^{124}$ and generally requires advance notice to existing priority-holders. ${ }^{125}$

In several states where oil, gas, and other minerals production is big industry, minerals producers recently lobbied their legislatures to enact statutes that turn the principle of first-in-time, first-in-right on its head. For example, Oklahoma legislation gives producers a so-called constructive trust on oil and gas sold on credit. ${ }^{126}$ Several other states have loosely analogous statutes. ${ }^{127}$

These types of distortions can undermine the commercial expectations of parties extending credit to minerals purchasers. In the case of the Oklahoma statute, for example, lenders have no way of knowing of the existence of the constructive trust, much less the amount of a producer's interest or the assets to which the trust attaches. ${ }^{128}$ Furthermore, the constructive trust may not even arise until after lenders have made their loans. ${ }^{129}$

120. Cf. supra note 24 and accompanying text (discussing the importance of preserving commercial expectations).

121. U.C.C. $\$ 9-322(2009)$.

122. Id. $\S 9-324$.

123. Id. § 9-324 off. cmt. 1 (stating that § 9-324 used to be former U.C.C. § 9-312(3)-(4)); Steve H. Nickles, Setting Farmers Free: Righting the Unintended Anomaly of UCC Section 9-312(2), 71 MINN. L. REV. 1135, 1191 (1987) ("The 1950 version [of the UCC] established the principle of first-to-file as the basic and residual rule of priority among conflicting security interests. The precursors to [former] sections 9-312(3) and 9312(4) were combined in a single section which provided that notwithstanding the rule of first-to-file, 'a purchase money security interest is prior to a conflicting interest in the same collateral under an after-acquired property clause."').

124. See, e.g., Gerard MCCORMACK, SECURED Credit UNDER English AND AMERICAN LAW 84-86 (2004) (justifying the priority for purchase-money security interests (PMSIs) based on the fact that the creditor releases funds to increase the debtor's total pool of assets from which the debtor acquires new assets).

125. U.C.C. $§ 9-324(b)(2)-(4)$ (2000) (requiring advance notice to holders of security interests in the same inventory).

126. Oklahoma Production Revenue Standards Act (PRSA), (codified at OKLA. STAT. tit. $52 \S 570.10$ (1995)).

127. For example, Texas and Kansas legislation create automatic, purportedly first-priority, liens in favor of producers to secure the purchase price of minerals sold to first purchasers of the minerals. TX. BUS. \& COMM. CODE ANN. § 9.343 (2005); KAN. STAT. ANN. § 84-9-339a (2006).

128. The Oklahoma statute has no notice requirement, nor does it create an express trust; indeed, PRSA $\S$ 570.10(A) states that "[n] othing in this subsection shall create an express trust." OKLA. STAT. tit. $52 \S 570.10$ (4). The only operative section of the statute merely states that "[a]ll proceeds from the sale of [oil and gas] production shall be regarded as separate and distinct from all other funds of any person receiving or holding the same until such time as such proceeds are paid to the" producers, and that "[a]ny person holding revenue or proceeds from the sale of [such] production shall hold such revenue or proceeds for the benefit of the" producers. Id.

129. See infra notes 129-134 and accompanying text (discussing the SemCrude litigation, in which the constructive trust arose after the banks had made their loans). 
Not surprisingly, these types of statutes have engendered litigation. In the most prominent dispute, a syndicate of banks had extended $\$ 3$ billion of credit to oil-and-gas company SemCrude, secured by a contractual lien on SemCrude's oil and gas inventory. ${ }^{130}$ The banks perfected that lien by filing financing statements, making them first in time, and thus first in right, under commercial law. ${ }^{131}$ Various oil producers thereafter sold oil to SemCrude on credit. ${ }^{132}$ When SemCrude filed for bankruptcy, the unpaid oil producers claimed that their then-arising constructive trust had priority over the banks' lien. ${ }^{133}$ At the time of this Article's publication, the case was being litigated, on appeal, in the Third Circuit Court of Appeals. ${ }^{134}$

Consider how this Article's framework would apply to priority reversal for minerals. The benefits of priority reversal accrue to producers of minerals, who thereby obtain first priority liens in the minerals to assure they are ultimately paid for the sale price of the minerals. But there are significant costs, both conceptually and real. Conceptually, priority reversal undermines a cornerstone of commercial law: the right of parties in commercial transactions to know in advance what is expected in order to assess consequences. Realistically, the uncertainty that priority reversal causes - financiers who are perfected cannot know their priority in minerals taken as collateral - can discourage financiers of mineral production and delivery, thereby potentially undermining the volume and price of production itself.

Priority-reversal laws for minerals thus seem at least somewhat self-defeating, calling into question why jurisdictions would enact them in the first place. At least one answer is that producers favoring these laws are local to the jurisdictions enacting them, ${ }^{135}$ whereas financiers tend to be located in other jurisdictions. ${ }^{136}$ In enacting these laws, legislators appear to focus on direct constituent interests, perhaps not fully taking into account indirect consequences, or externalizing at least a portion of those consequences onto out-of-jurisdiction financiers.

A precise numerical comparison of the benefits and costs of priority reversal may not be feasible, but it is almost certainly the case that the benefits do not heavily outweigh the costs. Besides the fact that priority-reversal laws for minerals are at least somewhat self-defeating, these laws merely minimize the transaction costs by which producers could contractually protect their own interests. For example, producers concerned about being paid for the sale of minerals could protect their right to payment through contractual security interests in the minerals. A producer who is concerned that this security interest may be subordinate to the prior security interest of a financier could negotiate a purchase-money security interest in the minerals. Such a purchase-money security interest would reverse the financier's first priority; but that could only occur after

130. In re SemCrude, L.P., 399 B.R. 388 (Bankr. D. Del. 2009), aff'd, 1010 WL 1737103 (D. Del 2010).

The author has acted as an expert witness for the banks in this case.

131. Id.

132. Id.

133. Id.

134. Id.

135. The Texas, Oklahoma, and Kansas priority-reversal statutes, for example, cover oil-and-gas producers located within those states.

136. In the SemCrude case, for example, the financiers were large, money-center banks located in other jurisdictions. 
notice to the financier, enabling the financier to decide not to extend further financing. ${ }^{137}$

The foregoing balancing is normative, but it raises the question-particularly applicable to a federal system that applies a principle of full faith and credit - of the extent to which a jurisdiction enacting law that implements a distortion of legal principles should take into account the consequences of the distortion on other jurisdictions. That question is beyond this Article's scope.

\section{Repo and Derivative Exemptions}

The characterization of certain types of basic legal agreements as being "special" when they pertain to financial assets, and subsequent statutory amendments to exempt parties to those agreements from ordinary legal rights and obligations, have significantly distorted legal principles with potentially negative consequences. First consider repurchase agreements (repos).

In a repo transaction, one party purports to sell a financial asset-typically securities - to another party, promising to "repurchase" the asset at a later time. ${ }^{138}$ In form, this is a sale. The purchase price, however, normally reflects a market-interest rate of return on the amount originally advanced as a purchase price. ${ }^{139}$ In economic substance, therefore, the transaction is a secured loan. ${ }^{140}$

The divergence between the form and substance of a repo transaction created a degree of uncertainty whether a given repo transaction should be treated as a sale or a loan in the event of a repo-participant's bankruptcy. ${ }^{141}$ Many repo-industry participants preferred sale treatment, which would protect their interests - although at the cost of their creditors. ${ }^{142}$

Repo-industry participants therefore lobbied for amendments to federal bankruptcy law to legislatively treat all repo transactions as sales, regardless of their economic substance. ${ }^{143}$ In 2005, Congress amended bankruptcy law to accomplish this, ${ }^{144}$ thereby

137. See U.C.C. $§ 9-324$ (b) (2009) (providing that as purchase-money security interest in inventory has priority over a conflicting security interest in the same inventory only if, inter alia, the purchase-money secured party "sends an authenticated notification to the holder of the conflicting security interest" describing the conflict). Official Comment 4 to this UCC section explains that this notification requirement "protects the nonpurchase-money inventory secured party" by enabling it to decide to no longer advance funds. Id. $\S 9-324$ off. cmt. 4.

138. Scott Besley \& Eugene F. Brigham, Principles of Finance 29 (4th ed.)(2008).

139. Id.

140. Kenneth C. Kettering, True Sale of Receivables: A Purposive Analysis, 16 AM. BANKR. InST. L. REV. 511, 552-53 (2008); Luc Thévenoz, Intermediated Securities, Legal Risk, and the International Harmonization of Commercial Law, 13 StAN. J.L. BuS. \& FIN. 384, 452 n.150 (2008). See also Jeanne L. Schroeder, A Repo Opera: How Ginnie Mae Got Repos Backwards, 76 AM. BANKR. L.J. 565, 572 (2002) ("Repos are substantially equivalent to secured loans for economic purposes. Both are financing devices whereby one party provides the other with funds against the promise that the funds be paid back in the future, and which promise is assured through the transfer of a property interest in investment securities.").

141. Edward R. Morrison \& Joerg Riegel, Financial Contracts and the New Bankruptcy Code: Insulating Markets from Bankrupt Debtors and Bankruptcy Judges, 13 AM. BANKR. INST. L. REV. 641, 654-55 (2005).

142. Id. See infra note 145 (explaining that the rationale for requiring substantive indicia of a sale is that ownership transfer affects not merely the contracting parties but also imposes externalities on creditors).

143. See Mark Roe, End Bankruptcy Priority for Derivatives, Repos and Swaps, FIN. TIMES OPINION, Dec. 15, 2009, available at http://www.ft.com/cms/s/0/16da702e-ea41-11de-aeb6-00144feab49a.html ("Derivatives, repos and financial swaps - the huge financial market in protection against foreign exchange and interest rate 
distorting, in the repo context, the generally accepted principle that a sale must shift at least some of the benefits and burdens of ownership. ${ }^{145}$ As a result, parties can now bypass most bankruptcy-law rights and obligations simply by characterizing their transactions as repos. ${ }^{146}$

More recently, at the instigation of lobbyists for the derivatives industry, Congress amended bankruptcy law to similarly exempt derivatives transactions from most bankruptcy-law rights and obligations. Derivatives transactions are, in their most fundamental form, transactions in which one or more parties agree to make payments or deliveries to the other based on how a reference item performs or changes in value. ${ }^{147}$ The concept is so broad, however, that even a simple unsecured loan agreement can be couched as a derivatives transaction. ${ }^{148}$ As a result, the recent amendments exempt a wide swath of - some would say virtually all — financial contracts from bankruptcy-law rights and obligations simply by reason of such contracts being couched as derivatives contracts. ${ }^{149}$ This is a distortion that exalts form over substance because derivatives transactions "differ little in substance from [ordinary] transactions, such as secured loans." 150

Consider how this Article's framework would apply to repo and derivatives exemptions. The ostensible benefit for these exemptions is to mitigate systemic risk by enabling solvent parties to terminate these contracts with bankrupt parties, thereby preventing market disruption. ${ }^{151}$ Although the extent to which these exemptions are effective to mitigate that risk "is ultimately an empirical question," 152 the precautionary

fluctuations, in liquidity-enhancing transactions, and in guarantees against loan defaults - are treated extremely favourably in bankruptcy law. It has been a successful lobbying effort for this part of the American financial industry: priority treatment is important for the industry, but not well enough understood to engage much public attention beyond the financial press."). It is somewhat ironic that this distortion was intended in part to mitigate uncertainty.

144. Bankruptcy Abuse Prevention and Consumer Protection Act of 2005 (BAPCPA), Pub. L. No. 109-8, 119 Stat. 23 (codified at 11 U.S.C. $\$ 559$ (2006)).

145. See, e.g., Major's Furniture Mart, Inc. v. Castle Credit Corp., 602 F.2d 538, 544 (3d Cir. 1979). The rationale for requiring substantive indicia of a sale is that ownership transfer affects not merely the contracting parties but also imposes externalities on creditors. STEVEN L. SCHWARCZ ET AL., SECURITIZATION, STRUCTURED FINANCE \& CAPITAL MARKETS 71 (2004) (observing that, in determining whether a sale occurs, courts look to "factors ... indicative of whether the [transferor] truly parted with the future economic risks and benefits of ownership . . . and whether the [transferee] has taken on those risks and benefits").

146. Morrison \& Riegel, supra note 141, at 656-57.

147. Mark A. Guinn \& William L. Harvey, Taking OTC Derivative Contracts as Collateral, 57 BUS. LAW. 1127,1128 (2000). The reference item or subject can be anything-e.g., a financial instrument, an interest rate, or an event of default. $I d$. at 1128-29.

148. Morrison \& Riegel, supra note 141, at 653-58; Franklin R. Edwards \& Edward R. Morrison, Derivatives and the Bankruptcy Code: Why the Special Treatment?, 22 YALE J. REG. 91, 119-22 (2005); Rhett G. Campbell, Financial Markets Contracts and BAPCPA, 79 AM. BANKR. L.J. 697, 697, 703 (2005).

149. Cf. Morrison \& Riegel, supra note 141, at 651-52 (observing that the 2005 Bankruptcy Code amendments included "virtually every contract traded in derivatives markets, including particular contractsoptions, forwards, and certain futures - that are given more limited protection elsewhere in the [Bankruptcy] Code" while also extending protection to every party in a derivatives contract).

150. Morrison \& Riegel, supra note 141, at 644.

151. Schwarcz, Systemic Risk, supra note 44, at 219-20 (observing that these exemptions are aimed at mitigating systemic risk).

152. Id. at 220 . 
principle, if applied, would presume that the benefits of restricting that risk through the exemptions will exceed the costs. ${ }^{153}$ That does not, however, constitute a presumption that those benefits will "heavily" exceed those costs. Those costs would include the ability of parties to bypass fundamental bankruptcy-law rights and obligations by characterizing secured loans as repos or by characterizing even ordinary commercial transactions, including loans, as derivatives.

Although it is difficult to know if the benefits of these exemptions would heavily outweigh their costs, the potential ambiguity presents an opportunity for finding compromises that preserve the benefits of the exemptions while reducing their costs. As this Article was being published, the National Bankruptcy Conference (NBC) proposed this precise approach in a letter to Congress to narrow these exemptions. ${ }^{154}$ The NBC first observed that "bankruptcy professionals, academicians and others" have raised "significant concern" as to whether these exemptions "are unnecessarily broad." 155 The NBC then questioned "whether the exemptions are currently drafted so broadly that they would exempt from the Bankruptcy Code various non-financial-contract commercial transactions for which the normal rules of bankruptcy should govern, and thereby undermine the goals of the Bankruptcy Code." 156 The NBC went on to express its "concern[] that the breadth of the current exemptions affords parties the opportunity voluntarily to structure ordinary commercial transactions, such as loans or supply agreements, as financial contracts in order to fall within the exemptions and avoid the normal rules of bankruptcy. ..." ${ }^{157}$ A better approach, the NBC concluded, would be to narrow the scope of the exemptions to avoid exempting "transactions [that] pose no or little systemic risk." 158

\section{Restatement of the Framework}

Part III used the distortion of nemo dat caused by rehypothecation to derive a framework for assessing distortions of legal principles. Part IV.A-C tested and expanded that framework in the context of other distortions. Restating the expanded framework, the consequences (measured by costs and benefits) of allowing or disallowing distortions of legal principles should be balanced under a heavily-outweigh test. A distortion should be allowed only if its benefits would heavily outweigh its costs.

Any application of the framework must be tempered by the fact that a quantitative analysis is no better than its assumptions and data. Sometimes costs and benefits can be reasonably estimated, as appears to be the case for the distortion caused by automatic perfection. Other times, however, the costs or benefits cannot be reliably estimated. In the latter case, even when one cannot determine, within this Article's framework, whether the benefits of allowing the distortion would heavily outweigh its costs, the framework

153. See supra note 87 and accompanying text.

154. Letter from Edwin E. Smith, Chair, Committee on Capital Markets, National Bankruptcy Conference, to John Conyers, Jr., Chairman, Committee on the Judiciary, United States House of Representatives (Mar. 15, 2010) available at http://www.nbconf.com/pubs/NBC\%20Fin $\% 20$ Contracts $\% 20 \mathrm{Ltr} \% 20 \mathrm{MAR} \% 2015 \%$ 2020100001.pdf.

155. Id. at $1-2$.

156. Id. at 2 .

157. Id.

158. Id. 
provides a useful way of thinking about the problem of whether or not to allow the distortion.

Sometimes the costs of a distortion cannot be reliably estimated; but, as in the case of rehypothecation, they could be catastrophic. In those cases, it may well be appropriate to apply a precautionary principle, enabling regulators to disallow or at least regulate the distortion notwithstanding lack of decisive evidence of its net harm. Although that might be viewed as a harsh result, it would encourage parties to explore lower-cost alternatives for engaging in the beneficial activities underlying the distortion.

The analysis recognizes that a long-standing distortion of a legal principle may become so generally accepted over time that it no longer is likely to distort the principle in an unexpected way. Such a long-standing distortion might have trivial consequences, ultimately devolving into a mere exception to the principle - as in the case of the holderin-due-course exception to nemo dat. Although a complete balancing of costs and benefits of a distortion should theoretically take into account the costs of adapting to the distortion and the reduction in distortion costs as such adaption occurs, changing adaptation costs would be inherently difficult to measure. Adaptation costs are also likely to be much lower than direct costs. The framework therefore treats them as relatively insignificant for computational purposes. Part V addresses contexts in which individuals and institutions could apply the framework.

\section{UTILITY OF THE FRAMEWORK}

At least three categories of persons are likely to be confronted with the problem of distorting legal principles in contexts where they ought to be able to recognize the problem and attempt to address it. First, government lawmakers (such as legislators and agency administrators) will confront the problem when they consider enacting laws or promulgating rules that might distort legal principles. Second, judges will confront the problem when they consider enforcing transactions that rely on distorted legal principles. Third, lawyers will confront the problem when they represent clients who engage in transactions that distort legal principles or in litigation regarding those transactions. ${ }^{159}$

159. These perspectives on how government lawmakers, judges, and lawyers will confront the problem of distorting legal principles are consistent with a model of how distortions of legal principles might arise. Sometimes a party favoring a distortion will simply contract for it, ignoring any externalities the distortion may cause. This was how rehypothecation was handled until relatively recently, for example. See supra note 36 (citing sources that show how intermediaries lobbied to exempt rehypothecated securities from commercial-law protections). Under such a purely contractual approach, the distortion might not be enforceable, even as a matter of positive law. See, e.g., Steven L. Schwarcz, Rethinking Freedom of Contract: A Bankruptcy Paradigm, 77 TEX. L. REV. 515, 551-76 (1999) (examining why contracts causing externalities are not always enforced). Other times, a party or interest group favoring a distortion will lobby for legislation helping to implement it. Thus, rehypothecation was lobbied by investment bankers; automatic perfection was implemented by an amendment to the UCC, lobbied by the banking industry; priority reversal for minerals was implemented by amendments to state law, lobbied by minerals producers; and repo and derivatives exemptions were implemented by amendments to federal bankruptcy law, lobbied by repo-participants and derivatives counterparties. Once the legislation is enacted, the distortion may be automatic or may be accomplished contractually within the scope of the legislation. Rehypothecation, for example, still requires contractual agreement of the parties, whereas priority reversal for minerals is sometimes automatic and sometimes requires contractual agreement of the parties. Legislation specially lobbied to implement distortions may or may not be widely known, and sometimes may be virtually unknown to persons outside the relevant industry sector. See 
A fourth category of persons who might be seen as having responsibility for the problem of distorting legal principles-indeed, who might be seen as the primary protagonists of the problem - are non-lawyers who lobby government lawmakers to enact laws or promulgate rules that might distort legal principles; or who are parties in the lawsuits where judges consider enforcing transactions that rely on distorted legal principles; or who are clients instructing their lawyers to engage in those transactions. I do not believe it would be realistic, however, to expect non-lawyers to recognize or appreciate the problem (much less to be neutral about the problem should they recognize it). The responsibility to recognize and address the problem should fall on their legal counsel. ${ }^{160}$

A threshold question is thus how to identify distortions. To that end, lawmakers, judges, and lawyers should try to maintain an awareness of what constitutes such a distortion: a change in law that changes in an unexpected way a legal principle that is so generally accepted within a legal system as to form a basis for reasoning. ${ }^{161}$ Because this is an inherently conceptual definition, even a diligent lawmaker, judge, or lawyer may sometimes fail to identify a distortion. Although it might turn out to be easier to identify these distortions than to define them ex ante, this is not unlike the observation that it is easier to identify pornography than to define it-the "know-it-when-one-sees-it" quality. ${ }^{162}$ But even if identification is imperfect and some distortions are missed, good can be done when a distortion is identified. ${ }^{163}$ The discussion below examines how this Article's framework could be applied to government lawmaking, judicial decisionmaking, and lawyering.

\section{A. Application to Government Lawmaking}

This Article's framework has its most apt application to government lawmakers, who would view distortions of legal principles in a law- or rule-making context. As discussed, although a simple positive cost-benefit balancing makes sense for assessing legislation or rules that are at least theoretically neutral as to any given group, the impact should not be presumed to be inherently neutral when private interest groups are lobbying for distortions that could impose externalities on third parties. The lobbying parties would almost certainly get a disproportionate share of the benefits, with the public potentially suffering a disproportionate share of any harms. ${ }^{164}$ The heavily-outweigh balancing test

supra Part IV.B (indicating that state laws reversing minerals priorities have been virtually unknown outside the oil-and-gas industry).

160. See supra note 159 and accompanying text.

161. See supra notes 20-23 and accompanying text.

162. See Jacobellis v. Ohio, 378 U.S. 184, 197 (1964) (Stewart, J., concurring) ("I shall not today attempt further to define the kinds of material I understand to be embraced within that shorthand description [of pornography]; and perhaps I could never succeed in intelligibly doing so. But I know it when I see it, and the motion picture involved in this case is not that.").

163. Cf. Voltaire, La Begueule, Conte Moral, A3 (1772) (observing that "Le mieux est l'ennemi du bien," or the best is the enemy of the good).

164. Cf. Frank Ackerman \& Lisa Heinzerling, Pricing the Priceless: Cost-Benefit Analysis of Environmental Protection, 150 U. PA. L. REV. 1553, 1576 (2002) (arguing that "[p]eople with strong, and clashing, partisan positions naturally will advocate that discretion in the application of [cost-benefit] methodology be exercised in favor of their positions, further undermining the claim that cost-benefit analysis is objective"). 
of this Article's framework is intended to help offset that disparity.

In applying this balancing test, lawmakers need to identify and quantify the costs and benefits of the proposed law or rule. That can be done the same way that lawmakers presently do it when engaged in traditional cost-benefit analyses. ${ }^{165}$

It therefore would appear straightforward to apply this Article's framework to distortions of legal principles in a law- or rule-making context. But such application raises a broader normative question ${ }^{166}$ of how government lawmakers should view their duties to the public: should something like a heavily-outweigh balancing test be generally applicable to offset disparities caused by lobbying? ${ }^{167}$ It may well be the case, for example, that elected lawmakers, like legislators, should have more flexibility in weighing consequences than nonelected rule makers like administrative agency officials. This broader question, however, is beyond the scope of this Article.

\section{B. Application to Judicial Decision-Making}

Judges would view distortions of legal principles in an adjudicatory context. In that context, and indeed in a scenario conceptually similar to the distortion problem, this Article has shown that courts often apply a heavily-outweigh cost-benefit balancing test. 168

Applying the framework's heavily-outweigh test to distortions would raise at least two issues for judges. First, to the extent distortions of legal principles have been incorporated into positive law, there is a recursive problem insofar as judges view their job as enforcing positive law. ${ }^{169}$ Indeed, the process of enacting positive law is objective,

165. For a discussion of how lawmakers presently identify and quantify costs and benefits of proposed legislation and administrative rules, $c f$. Ackerman \& Heinzerling, supra note 164, at 1556-60 (discussing costbenefit analysis in the context of environmental regulation, including estimating costs through research into available technologies and compliance strategies, monetizing benefits through opinion polls and human behavior, and discounting future costs and benefits to present value). President Reagan's Executive Order 12291 and President Clinton's Executive Order 12866 have required federal agencies to prepare a regulatory impact analysis that considers all quantifiable and non-quantifiable benefits and costs, and also have required the Office of Management and Budget (OMB) to oversee these regulatory analyses. Congress also has adopted cost-benefit analysis to assess the efficiency and economics of proposed regulations. Robert W. Hahn \& Patrick Dudley, How Well Does the Government Do Cost-Benefit Analysis?, 3-5 (AEI-Brookings Joint Center Working Paper, Paper No. 04-01, at 3-5, January 2004), available at http://papers.ssrn.com/sol3/papers.cfm?abstract_id=495462.

166. Such application also raises a federalism question, discussed in the text following note 137, supra.

167. Cf. Vincent R. Johnson, Regulating Lobbyists: Law, Ethics, and Public Policy, 16 CORNELL J. L. \& PUB. POL'Y. 1, 2-4 (2006) (observing general concerns over the distorting influence of lobbying with respect to governmental decision-making, and the criticisms of the effectiveness of the legal rules enacted at all levels of American government to prevent this); see generally JOSEPH SCHUMPETER, CAPITALISM, SOCIALISM AND DEMOCRACY (1942) (analyzing the extent to which an upheaval to one party is justified by a social benefit). Also cf. supra note 119 (discussing whether a heavily-outweigh test should be applied when legislating distortions intended to benefit only specific groups).

168. See supra notes 49-53 and accompanying text (examining use of a heavily-outweigh balancing test in substantive consolidation cases).

169. See, e.g., James Bernard Murphy, The Philosophy of Positive Law: Foundations of JURISPRUDENCE 2-3 (2005) (describing philosophy of positive law). See also Alexandra B. Klass, Common Law and Federalism in the Age of the Regulatory State, 92 IowA L. REV. 545, 549-50 (2007) (discussing the view of Justice Oliver Wendell Holmes that the "judge's role was to enforce positive law"). 
and "process" is central to law's legitimacy. ${ }^{170}$ In contrast, this Article has shown that identifying a distortion of a legal principle and weighing its costs and benefits can be quite subjective. It therefore appears that judges should enforce transactions that rely on distorted legal principles that have been enacted into positive law.

This is not to say that judges should be reticent to express any reluctance they may have in their opinions. And some judges might go - and in similar cases have actually gone - even further, stretching to distinguish the case so as to reach a desired result. ${ }^{171}$

The other issue in applying this Article's framework is a judge's institutional limitations. Judges sometimes may find it difficult, for example, to accurately assess the costs and benefits of a distortion. Although they could hear expert testimony for this purpose, that could be costly and the judge still would have to assess the merits of conflicting testimony. In appropriate cases, perhaps, courts could be assisted for this purpose by more independent experts, such as special masters.

\section{Application to Lawyering}

Lawyers would view distortions of legal principles in either a litigation or transactional context. In the litigation context, a lawyer would not necessarily make an independent normative judgment about the client's case; even a wrongdoer is entitled to a day in court represented by counsel. The more interesting context is transactional, such as when a client instructs a lawyer to draft something that distorts legal principles, such as a rehypothecation agreement. ${ }^{172}$ Applying the framework's heavily-outweigh test would raise several issues.

The first issue is how to assess costs and benefits. Trained in law, and not necessarily in economics or empirical analysis, most lawyers would find this task difficult. Furthermore, even lawyers willing to undertake this task may well miscalculate costs and benefits.

These difficulties help to inform the second issue, which is whether lawyers should

170. ERwin Chemerinsky, Constitutional Law: Principles And Policies 547 (3d ed. 2006) ("The concept of procedural due process never has been controversial, although there certainly have been major disputes over what constitutes liberty and property interests and what procedure should be required. In contrast, the very idea of substantive due process has been contested. The argument is that due process denotes procedures and that it is incorrect to use the due process clause as the place for protecting substantive rights."); JOHN HART ElY, DEMOCRACY AND DiSTRUST 18 (1980) ("No evidence exists that 'process' meant something different a century ago from what it does now . . . . and it should take more than the occasional aberrational use to establish that those who ratified the Fourteenth Amendment had an eccentric definition in mind. Familiarity breeds inattention, and we apparently need periodic reminding that 'substantive due process' is a contradiction in terms - sort of like 'green pastel redness."').

171. See, e.g., In re Nat'l Gas Distribs., LLC, 369 B.R. 884, 889-900 (Bankr. E.D.N.C. 2007) (narrowly reasoning that natural gas supply contracts were not "swap agreements" under bankruptcy law because they involved the physical delivery of the commodity to an end user and were not traded in the financial markets), rev'd on appeal, 51 B.C.D. 56 (4th Cir. 2009). But cf. Morrison \& Riegel, supra note 141, at 644 (arguing that "any judicial effort to distinguish protected and unprotected contracts based on their 'substance' is doomed to failure and can only generate significant uncertainty in the very markets the [Bankruptcy] Code seeks to protect," and that by "relying on broad market definitions, the [amendments] get[] judges out of the (largely futile) business of second-guessing financial contracts").

172. Cf. Steven L. Schwarcz, The Limits of Lawyering: Legal Opinions in Structured Finance, 84 TEX. L. REV. 1, 28-30 (2005) (examining the extent to which lawyers should provide legal opinions to facilitate bargained-for transactions that comply with positive law but nonetheless have negative externalities). 
have a duty to refuse to help a client distort legal principles. Imposing such a duty would place the lawyer in an impossible situation: the lawyer's duty to resign would turn on an assessment that most lawyers are incapable of accurately making. The imposition of that duty would also create a potential conflict between the lawyer and the client. This Article therefore does not propose such a duty. ${ }^{173}$

Some lawyers may nonetheless wish, for aspirational reasons or otherwise, to inform the client that its actions may distort a legal principle, and to withdraw from the engagement if the client persists in its action. Lawyers certainly should have the option to refuse to participate in conduct that may be socially harmful. ${ }^{174}$

The foregoing analysis assumes that distorting the legal principle will not itself violate positive law. If the distortion does violate positive law, the lawyer would have a duty to not engage or assist the client in performing an unlawful act. ${ }^{175}$ The lawyer should then try to persuade the client to comply with the law and, if unsuccessful, ultimately may have to resign.

\section{CONCLUSION}

Although legal principles enable society to order itself by preserving broadly based expectations, parties sometimes transact in ways that are so inconsistent with generally accepted principles as to create uncertainty or confusion that undermines the basis for reasoning afforded by the principle. That type of uncertainty was a trigger of Lehman Brothers' recent downfall, when a practice known as rehypothecation distorted the nemo dat principle (one cannot give what one does not have). As a result, Lehman's customers, uncertain whether their investments could be attached by Lehman's creditors, withdrew those investments on rumors of the firm's insolvency. Much like a "run on the bank," that inadvertently triggered, or at least significantly contributed to, Lehman's collapse.

This Article constructs a normative framework for determining how government lawmakers, judges, and lawyers should address distortions of legal principles. Not all such distortions have net costs; sometimes they represent a positive evolution of law. Therefore, any normative framework should attempt to balance costs and benefits. However a simple balancing test would be misleading because parties advocating the distortion would almost certainly receive a disproportionate share of the benefits, with the

173. Cf. Steven L. Schwarcz, Reply-We Are All Saying Much the Same Thing: A Rejoinder to the Comments of Professors Coffee, Macey, and Simon, 84 TEX. L. REV. 93, 101-02 n.58 (2005) (discussing the observation of legal ethicist Richard Painter that although it is "sound in principal" for a lawyer to embrace aspirational goals, vague aspirational goals might serve as a "definition of professionalism" but should not be used to "impose liability on lawyers").

174. Cf. Model Rules of Prof'L Conduct R. 2.1 (2007) (providing that "[i]n rendering advice, a lawyer may refer not only to law but to other considerations such as moral, economic, social and political factors, that may be relevant to the client's situation"); William H. Simon, Earnings Management as a Professional Responsibility Problem, 84 TEX. L. REV. 83, 88 (2005) (arguing that lawyers should not participate in conduct that is "socially harmful"); Steven L. Schwarcz, Keynote Address: The Role of Lawyers in the Global Financial Crisis, Australian J. CORP. L. (forthcoming 2010) (in the context of examining the duty of lawyers to the public, discussing the right of a lawyer to refuse to participate in conduct that may be socially harmful).

175. See, e.g., Restatement (ThiRd) Of The Law Governing LaWYers $\S 16 \mathrm{cmt}$. c (2000) (“A lawyer may not do or assist an unlawful act on behalf of a client ...."); MODEL RULES OF PROF'L CONDUCT R.1.2(d) (2007) ("A lawyer shall not counsel a client to engage, or assist a client in conduct that the lawyer knows is criminal ...."). 
public potentially suffering a disproportionate share of any harm.

In this potentially biased context, and because of the risk of significant public harm, this Article argues that distortions of legal principles should be assessed not on a simple cost-benefit basis but by a higher standard. Because the parties enjoying the benefits of the distortion are not necessarily the parties suffering the costs, a heavily-outweigh balancing test can help to rebalance the distributive effects. This type of test also recognizes that the consequences of these distortions are difficult to anticipate and quantify; the test requires any benefits to be large in order to offset unknown or undervalued costs. Even when costs and benefits are indeterminate, however, this Article shows that the test provides a useful way of thinking about the problem of distorting legal principles. 